\title{
Guarantee and Intervention: the Assessment of the Peace of Westphalia in International Law and Politics by Authors of Natural Law and of Public Law, c. 1650-1806
}

\author{
Patrick Milton
}

\section{1 \\ Introduction}

The Peace of Westphalia is simultaneously one of the most thoroughly researched, and one of the most misunderstood peace settlements of early modern history, albeit not by the same people. The fact that this paradox has persisted in the last two decades, when detailed historical research into the treaties of Münster (Instrumentum Pacis Monasteriensis, IPM) and Osnabrück (Instrumentum Pacis Osnabrugensis, IPO $)^{1}$ and their implications has been booming, is indicative of the tenacity of the myth surrounding Westphalia. ${ }^{2}$ Broadly, the misperception of Westphalia has two dimensions, the international - according to which the Peace inaugurated a new international 'Westphalian system' of equal, sovereign states which do not intervene in each other's domestic affairs ${ }^{3}$ - and the internal-constitutional, which alleges that the treaties granted the princely territories (Imperial Estates) of the Holy Roman Empire

1 Both treaties together constituted the peace settlement that ended the Thirty Years' War and were both signed at Münster on 24 October 1648. See 'Internet-Portal "Westfälische Geschichte”, last modified 1 November 2004, http://www.lwl.org/westfaelische-geschichte/portal/Internet/finde/langDatensatz.php?urlID=740\&url_tabelle=tab_quelle (IPO), and http://www.lwl .org/westfaelische-geschichte/portal/Internet/finde/langDatensatz.php?urlID=741\&url_tabelle=tab_quelle (IPM).

2 For the latest research on Westphalia, see the literature cited in Niels F. May, Zwischen fürstlicher Repräsentation und adliger Statuspolitik: Das Kongresszeremoniell bei den westfälischen Friedensverhandlungen (Ostfildern: Jan Thorbecke, 2016).

3 E.g.: Arnaud Blin, 1648, la paix de Westphalie ou la naissance de l'Europe politique moderne (Bruxelles: Editions Complexe, 2006); Daniel Philpott, Revolutions in Sovereignty: How Ideas Shaped Modern International Relations (Princeton, NJ: Princeton University Press, 2001), 4, 30,85 . 
sovereignty. ${ }^{4}$ To a greater or lesser degree, some or all of these ascriptions have been repeated by political scientists, historians, scholars of international law, and legal historians. ${ }^{5} \mathrm{~A}$ rich body of research into the treaties and the Westphalian order, including several pieces which explicitly provide correctives to the misperceptions, have only partially dented the Westphalian myth. ${ }^{6}$

Many scholars have viewed natural law as an ideological tool used by early modern rulers in the pursuit of princely absolutism, which helped the territorial state to overcome corporate rights and customary practice, ${ }^{7}$ in order to realize the potential of sovereignty and absolute authority supposedly inherent in the Westphalian settlement. In the eighteenth-century Holy Roman Empire, natural law was used by the princes to legitimate the streamlining and centralizing of administration and law in the territories, which often included attempts to sweep away the customary privileges of the territorial estates, and to inhibit the possibilities of appeals to the higher

4 E.g.: Derek Beales, Joseph II, vol 2: Against the World, 1780-1790 (Cambridge: Cambridge University Press, 1987), 410-411; Michael Hughes, Law and Politics in Eighteenth Century Germany: The Imperial Aulic Council in the Reign of Charles VI (Woodbridge: Boydell Press, 1988), 16-17; James Sheehan, German History, 1770-1866 (Oxford: Clarendon Press, 1989), 16; Albrecht Randelzhofer, Völkerrechtliche Aspekte des Heiligen Römischen Reiches nach 1648 (Berlin: Duncker \& Humblot, 1967), passim.

5 E.g.: Gene Martin Lyons and Michael Mastanduno, Beyond Westphalia? State sovereignty and international intervention (Baltimore, MD: Johns Hopkins University Press, 1995); Sasson Sofer, 'The Prominence of Historical Demarcations: Westphalia and the New World Order', Diplomacy and Statecraft 20, no. 1 (2009): 1-19.

6 Derek Croxton, The Last Christian Peace: The Congress of Westphalia as A Baroque Event (Basingstoke: Palgrave Macmillan, 2013), 351-362; Heinz Duchhardt, 'Das "Westfälische System": Realität und Mythos,' in Akteure der Außenbeziehungen. Netzwerke und Interkulturalität im Historischen Wandel, ed. Hillard von Thiessen and Christian Windler (Cologne: Böhlau, 2010), 393-402; Georg Schmidt, 'Der Westfälische Frieden - eine neue Ordnung für das alte Reich?', in Wendemarken in der Deutschen Verfassungsgeschichte: Tagung der Vereinigung für Verfassungsgeschichte, ed. Reinhard Mußgnug (Berlin: Duncker \& Humblot, 1993), 45-84; Johannes Burkhardt, 'Der Westfälische Friede und die Legende von der landesherrlichen Souveränität,' in Landes- und Reichsgeschichte: Festschrift für Hansgeorg Molitor zum 65. Geburtstag, ed. Jörg Engelbrecht and Stephan Laux (Bielefeld: Verlag für Regionalgeschichte, 2004), 199-220; Peter H. Wilson, Europe's Tragedy: A New History of the Thirty Years War (London: Penguin Books, 2010), 776-778; Derek Croxton, "The peace of Westphalia of 1648 and the origins of sovereignty', International History Review 21, no. 3 (1999): 569-591; Andreas Osiander, 'Sovereignty, international relations, and the Westphalian myth,' International Organization 55, no. 2 (2001): 251-287; Stephane Beaulac, 'The Westphalian legal orthodoxy myth or reality?', Journal of the History of International Law 2 (2000): 148-177.

7 E.g.: Michael Stolleis, Geschichte des öffentlichen Rechts in Deutschland, vol. 1 (Munich: C.H. Beck, 1988), 276-277; Notker Hammerstein, 'Christian Thomasius,' in Politische Theorien des 17. und 18. Jahrhunderts: Staat und Politik in Deutschland, ed. Bernd Heidenreich and Gerhard Göhler (Darmstadt: Philipp von Zabern, 2011), 123-124, 131. 
(extra-territorial) judicial tribunals of the Empire. ${ }^{8}$ While such arguments are illuminating with regard to strategies of princely rule and consolidation, they also sometimes perpetuate the misperceptions about the treaties of Westphalia. ${ }^{9}$ This is not surprising, however, in light of the interpretations of Westphalia by several early modern theorists of natural law themselves, such as Gottfried Wilhelm Leibniz, Emer de Vattel and Gottfried Achenwall, who varyingly viewed Westphalia as a charter for absolutism within the framework of the Empire, or the final stage in the evolution of the Empire into an overarching system of sovereign states. ${ }^{10}$ Thus, the mythologizing of

8 Knud Haakonssen, 'German natural law,' in The Cambridge History of Eighteenth-Century Political Thought ed. Mark Goldie and Robert Wokler (Cambridge: Cambridge University Press, 2006), 257. It is worth pointing out that discourses grounded in natural law were also cited by these very same Imperial authorities (chiefly the Reichshofrat - Imperial Aulic Council) when justifying punitive actions and interventions against princes for the protection of the traditional customary rights of their suppressed territorial estates and other subjects, as well as confessional and other rights confirmed at Westphalia, a fact which is insufficiently appreciated in the existing literature. In suspending the Duke of MecklenburgSchwerin from power, for example, the Reichshofrat argued that the duke's disregarding of the obligations detailed in treaties concluded by his predecessors with their subjects was contrary to natural law. See report by the Reichshofrat, 3 Nov. 1722: Haus- Hof- und Staatsarchiv, Vienna, RHR, Vota 34. See also Patrick Milton, 'Intervening against tyrannical rule in the Holy Roman Empire during the seventeenth and eighteenth centuries,' German History 33, no. 1 (2015): 1-29, and Robert von Friedeburg, 'Natural Jurisprudence, Argument from History and Constitutional Struggle in the Early Enlightenment: The Case of Gottlieb Samuel Treuer's Polemic Against Absolutism in 1719,' in Early Modern Natural Law Theories: Contexts and Strategies in the Early Enlightenment, ed. T.J. Hochstrasser and Peter Schröder (Dordrecht: Kluwer Academic Publisher, 2003), 141-168. Early modern practitioners and lawyers used an eclectic range of sometimes contradictory, sometimes reinforcing legal traditions in their argumentation: Haakonssen, 'German natural law', 259.

$9 \quad$ E.g.: Detlef Döring, 'Der Westfälische Frieden in der Sicht Samuel Pufendorfs,' Zeitschrift Für Historische Forschung 26, no. 3 (1999): 353, 358.

10 Gottfried Wilhelm Leibniz, Sämtliche Schriften und Briefe (Berlin: Akademie der Wissenschaften der DDR, 1983), series IV, vol. 2, 21; Emer de Vattel, The Law of Nations, Or, Principles of the Law of Nature, Applied to the Conduct and Affairs of Nations and Sovereigns, with Three Early Essays on the Origin and Nature of Natural Law and on Luxury, ed. Béa Kapossy and Richard Whatmore (Indianapolis, IN: Liberty Fund, 2008), 683-684; Gottfried Achenwall, Geschichte der allgemeineren Europäischen Staatshändel des vorigen und ietzigen Jahrhunderts im Grundriss der europäischen Geschichte (Göttingen: Verlag der Witwe Vandenhoeck, 1761), 84. Another aspect of the Westphalian myth that was already argued by some natural law writers is the notion that the treaties of 1648 granted Switzerland and the Dutch republic full independence from the Holy Roman Empire: e.g. Vattel, The Law of Nations, 212, 696. For a refutation thereof, see Siegrid Westphal, Der Westfälische Frieden (Munich: C.H. Beck, 2015), 105, and Croxton, Last Christian Peace, $354-35^{6 .}$ 
Westphalia began much earlier than is often assumed, beginning soon after the conclusion of the Peace itself.11

This leads to the broader question of how Westphalia in all its aspects and implications was perceived and assessed by writers in the tradition of the law of nature and nations, and how this differed from the reception of Westphalia in other traditions of seventeenth- and eighteenth-century legal and political thought. The literature on the Peace of Westphalia, both before and after the end of the Empire and therefore the Westphalian treaties' legal validity in 1806, is immense, and several modern scholars have addressed the question of the reception of the Peace among early modern jurists and philosophers. ${ }^{12}$ This literature mainly dealt with the confessional and constitutional stipulations of the IPO as applied within the Holy Roman Empire, and their implications in the subsequent 15 o years. ${ }^{13}$ Therefore, and in light of the theme of this volume, this chapter will address the assessment of those parts of the treaties which related to the law of nations, along with their subsequent impact and relevance. The most salient among these, because of its innovative nature, is the institution of the mutual guarantee (IPO art. 17, § 4-5; IPM § 115-116), and the impact this had on external interventionism. The focus will be on the assessment of Westphalia by natural law theorists while writing in different capacities, as authors of works of constitutional law, history and political tracts, for example. After all, these different roles were not as separate as modern scholarship might suggest, and such capacities often overlapped and intersected..$^{14}$ Furthermore, such texts were written through the lens of the authors' respective

11 While Leibniz and Christian Thomasius had ascribed extensive authority approximating sovereignty to the Imperial Estates, most authors in the later eighteenth century, such as Johann Jacob Moser and Johann Stephan Pütter, no longer shared these interpretations: Bernd Mathias Kremer, 'Die Interpretationen des Westfälischen Friedens durch die "Schulen" des Jus Publicum,' in Der Westfälische Friede: Diplomatie, politische Zäsur, kulturelles Umfeld, Rezeptionsgeschichte, ed. Heinz Duchhardt (Munich: Oldenbourg Verlag, 1998), 766-769.

12 For works published between 1648 and 1996, see Heinz Duchhardt, Eva Ortlieb, and Matthias Schnettger, ed., Bibliographie zum Westfälischen Frieden (Münster: Aschendorff Verlag, 1996). For works published after 1996, see the literature cited in Westphal, Der Westfälische Frieden.

13 Bernd Mathias Kremer, Der Westfälische Friede in der Deutung der Aufklärung. Zur Entwicklung des Verfassungsverständnisses im Hl. Röm. Reich Deutscher Nation vom Konfessionellen Zeitalter bis ins späte 18. Jahrhundert (Tübingen: Mohr, 1989); Döring, 'Der Westfälische Frieden in der Sicht Samuel Pufendorfs'.

14 Michael J. Seidler, 'Introduction,' in Samuel Pufendorf, An Introduction to the History of the Principal Kingdoms and States of Europe, ed. Michael J. Seidler, transl. Jodocus Crull (Indianapolis, IN: Liberty Fund, 2013), ix. 
understandings of natural law. This will be accompanied by the assessment of Westphalia by those writing on matters of international law who hailed from different intellectual traditions, primarily jus publicum. After briefly outlining the influence of Westphalia on the development of positive treaty law in the European legal order, the chapter will proceed by analysing how Westphalia and its impact were assessed by scholars of natural law, the law of nations, and public law, in terms of a general appraisal of the Peace, and the mutual guarantee along with foreign interventionism, both in theory and in practice.

\section{The Impact of the Treaties of Westphalia on the droit public de l'Europe}

While the Peace of Westphalia in many ways simply reaffirmed and enshrined existing constitutional conditions domestically within the Holy Roman Empire - albeit in an optimized and recalibrated set-up - internationally, it was one of the most innovative features in the law of nations. This is because the Westphalian treaties were simultaneously a fundamental constitutional law for the Empire, and an international peace treaty. As part of the measures designed to secure the longevity of the peace in IPO art. 17, the various contracting parties, including both sovereign European powers and the non-sovereign German Imperial Estates, mutually and reciprocally guaranteed the entire settlement, which was also recognized as a basic law of the Empire. This tied German public law to the law of nations, by creating an international responsibility to uphold the Imperial constitution, thereby arguably establishing a system of collective security for central Europe, which built on the 'Eternal Territorial Peace' that had been declared for the Empire in $1495 \cdot{ }^{15}$ The guarantee therefore anchored German constitutional law to a collective enforcement and compliance mechanism under international law. Westphalia thus added a further level to the legal hierarchy of Imperial Estates subordinated to the Emperor and Empire, by bestowing the 'external' guarantors, France and Sweden, ${ }^{16}$

15 SiegridWestphal, 'Reichskammergericht, Reichshofrat und Landfrieden als Schutzinstitute der Reichsverfassung,' in Schutz der Verfassung: Normen, Institutionen, Höchst- und Verfassungsgerichte, ed. Thomas Simon and Johanne Kalwoda (Berlin: Duncker \& Humblot, 2014), 13-37.

16 They were not technically external guarantors, as this would imply that a non-signatory third party such as a mediator had taken responsibility for the guarantee, which was not the case at Westphalia, where France, Sweden, the Emperor and the princes were all signatories and guarantors. For simplicity's sake, though, France and Sweden may be 
with a duty and a right to uphold the Imperial constitution by intervening under certain circumstances and after a specified sequence of steps. Other notable innovations which proved to be seminal in the law of nations include the instrument of the multilateral peace congress and the neutralization of religious canon law through the assertion of the primacy of secular law. ${ }^{17}$

Heinhard Steiger has demonstrated that the Peace of Westphalia cannot strictly be viewed as a fundamental basic law of Europe, contrary to the Westphalian myth. However, it left a clear imprint on subsequent treaty law, as a basic instance that was continuously mentioned in subsequent treaty texts, as a 'reference peace', and as a basic order that subsequent treaties sought to reaffirm and re-establish. It was specifically the guarantee which largely ensured that the treaties' immediate legal effects had a broader European scope than the internal constitutional matters of the Empire with which the settlement primarily dealt. For it was precisely in their capacity as guarantors of the peace that the signatories referred back to Westphalia and its guarantee when they concluded subsequent peace treaties, especially those involving the Empire. This was the case, for example, in the treaties of Nijmegen in 1679, Ryswick in 1697, Rastatt/Baden in 1714, and Teschen in 1779. Through these references, the basic order of Westphalia was reaffirmed by its guarantors as the 'foundation', 'fundamental norm' or 'unchangeable basis' of relations among them and within the Empire, following a temporary suspension during the preceding wars. ${ }^{18}$

Taking a longer-term perspective, it can plausibly be argued that by placing the confessional rights of religious groups under international guarantee, the Peace of Westphalia and its guarantee clauses helped to establish the principle of internationally guaranteed minority rights as a part of the positive law of nations. ${ }^{19}$ This, together with the experience over many years of peaceful, legally regulated confessional co-existence within the Empire, arguably contributed to the gradual emergence of the philosophical conviction of confessional toleration as a desirable principle within states, ${ }^{20}$ as well as minority rights

referred to as external guarantors, as the confessional-constitutional clauses of the treaties (which made up most of the treaty stipulations) applied only to the Holy Roman Empire.

17 Heinhard Steiger, 'Konkreter Friede und allgemeine Ordnung - zur rechtlichen Bedeutung der Verträge vom 24. Oktober 1648,' in 1648: Krieg und Frieden in Europa ed. Klaus Bußmann and Heinz Schilling (Munich: Bruckmann, 1998), 137-146.

18 Heinhard Steiger, 'Der Westfälische Frieden - Grundgesetz für Europa?' in Der Westfälische Friede, ed. Duchhardt, 33-8o. See also Croxton, Last Christian Peace, 363.

19 Steiger, 'Grundgesetz', 78.

20 This has recently been argued by Christoph Kampmann: 'Der Festgeschnürte Frieden: Prof. Christoph Kampmann erklärt ein Meisterwerk der Diplomatie,' P.M. History, May 2017. 
protection as a principle in the natural law-based jus gentium, beyond merely being partially stipulated by the Westphalian guarantee in the positive jus inter gentes.

The Peace of Westphalia seems to experience somewhat cyclical fortunes in its general appraisal by scholars and commentators over the years, which is remarkably reflective of the political context. While it was enthusiastically hailed as a milestone in early modern progressivism, and as a possible model for European unity around the turn of the millennium and specifically its 35oth anniversary, ${ }^{21}$ more measured evaluations have been proposed in recent years, although the appraisal is still very positive. Going back a step in history, verdicts in the nineteenth and the first two-thirds of the twentieth century were drastically different. Under the influence of the collapse of the Empire in 1806 and the subsequent Prussian drive for a new kleindeutsch empire which would be capable of power accretion and power projection, Westphalia was seen to mark the death knell of the old Reich as a political entity, the only advantage of which was that its impotence allowed Brandenburg-Prussia to rise and fulfil the mission of true national unification..$^{22}$ This negative view of Westphalia persisted remarkably long; as late as the 1950s and 196os the standard monograph on the Peace described it as a 'national misfortune' for the Germans. ${ }^{23}$

Going back further yet, jurists and writers of the seventeenth and eighteenth century again viewed the treaties in a completely different, largely positive, light, although assessments naturally differed and changed over the course of those 150 years or so. The almost uniformly negative perceptions which began to set in very soon after 1806 are in striking contrast to the favourable assessments of the Peace during the preceding period when the Empire still existed. However, it should be noted that, contrary to many accounts, the Peace was not unanimously eulogized over this period, even among Protestants. Bernd

21 E.g.Johannes Burkhardt, 'Das größte Friedenswerk der Neuzeit,' Geschichte in Wissenschaft und Unterricht 49 (1998): 592-612.

22 Johann Gustav Droysen, Geschichte der preußischen Politik, Dritter Teil, Der Staat des großen Kurfürsten, Erste Abteilung (Leipzig: Verlag von Veit und Comp., 1861), 61, 75; Heinrich von Treitschke, Deutsche Geschichte im 19. Jahrhundert (Leipzig: Verlag von S. Hirzel, 1879), vol. 1: 11-12; Leopold von Ranke, Französische Geschichte, vornehmlich des 16. und 17. Jahrhunderts, vol. 2 (Stuttgart: Koehler, 1954), 359-36o. 
Mathias Kremer has shown how shifting intellectual and normative currents affected scholars' evaluations of Westphalia, often leading to negative evaluations. ${ }^{24} \mathrm{~A}$ dissonance between the principles underpinning the treaty terms on the one hand, and subsequent prevailing mindsets and conceptions of constitutional and religious issues on the other hand, inevitably resulted in academic and intellectual debate on the merits or demerits of the continued validity of the terms of the Peace.

As a peace treaty and a constitutional law, the Peace of Westphalia ostensibly seems more relevant to public law than to natural law. Indeed, it immediately assumed a high priority in the curricula of teaching and training in public constitutional law, ${ }^{25}$ and according to the jurist Carl Friedrich Gerstlacher it virtually spawned a whole new jus publicum. ${ }^{26}$ Most of the writing on public law after 1648 dealt with questions which were all affected by a particular interpretation of IPO. $^{27}$ But the intellectual and philosophical shifts mentioned above were especially discernible among writers of natural law, as they were less concerned with compiling applicable positive law than with deriving underlying principles from it, and vice versa. ${ }^{28}$ Earlier theorists felt the need to defend the legitimacy of a legal-political inter-confessional peace, which failed to achieve a theological union, and Hermann Conring went to lengths to refute the legitimacy of the Papal protest against the Peace, something which would have seemed superfluous to later eighteenth-century natural law theorists. ${ }^{29}$ Westphalia's granting of limited, graded toleration, while ostensibly retaining

24 Kremer, Westfälischer Friede.

25 Konrad Repgen, 'Der Westfälische Friede: Ereignis und Erinnerung,' Historische Zeitschrift 267 (1998): 615-647.

26 Carl Friedrich Gerstlacher, Corpus Juris germanici publici et privati: das ist der möglichst ächte Text der teutschen Reichsgeseze, Reichsordnungen und andrer Reichsnormalien; in sistematischer Ordnung mit Anmerkungen (Karlsruhe: Schmieder, 1784), 310. Indeed, questions pertaining to the treaties gave rise to hundreds of mainly legal dissertations from the mid-seventeenth century: see Heinz Duchhardt, 'Münster und der Westfälische Friede - Kollektives Gedächtnis und Erinnerungskultur im Wandel der Zeit,' in Der Westfälische Friede, ed. Duchhardt, 856-857.

27 Joachim Whaley, Germany and the Holy Roman Empire (Oxford: Oxford University Press, 2012), vol. 2, 17 .

28 The foremost jurist of German public law, Johann Jacob Moser, criticized the tendency, as he viewed it, of natural law scholars to interpret Westphalia as they would like to see it, and also rejected their generalizing statements on the Imperial constitution: Johann Jacob Moser, Neues deutsches Staatsrecht (Stuttgart: Mezler, 1766), vol. 1, 527.

29 Kremer, Westfälischer Friede, 25-27. However, in $175^{8}$ Vattel still described the Pope's invalidation and statements of protest against Westphalia as 'violations of the law of nations', which 'directly tended to destroy all the bands that could unite mankind, and to sap the foundations of their tranquillity': Vattel, Law of Nations, 39 o. 
the Right of Reformation (jus reformandi), chimed with the conceptions of toleration, and of church-state relations of natural law writers such as Samuel Pufendorf and Christian Thomasius, whose conceptions thereof were likely affected by the experience of Westphalia and the modes of peaceful confessional co-existence introduced by the peace settlement. ${ }^{30}$

Most natural law theorists favoured the secularization of law and the desacralization of politics. ${ }^{31}$ However, the confessional terms of IPO were soon regarded, under the influence of the early Enlightenment, as resulting in an inadequate separation of church and state, and an excessively limited and circumscribed tolerance, by such writers as the Halle natural law professor Nicolaus Hieronymus Gundling, as well as by writers in the later Enlightenment such as Renatus Karl von Senkenberg, in even more vociferous terms. ${ }^{32}$ This applied in particular to the rigid freezing of confessional conditions and possessions according to the 'normative year', with the concomitant ability of princes to expel subjects whose religion had not been practised in the relevant territory on 1 January $1624,{ }^{33}$ and the continued ban on sects and religions other than Catholicism, Lutheranism and Calvinism. Senkenberg asked himself 'whether these stipulations are still valid' and answered: 'let all these provisions of the Peace of Westphalia which run contrary to natural law be considered invalid! They have not yet been explicitly abrogated, but since the

30 Samuel Pufendorf, of the Nature and Qualification of Religion in Reference to Civil Society, ed. Simone Zurbuchen, transl. Jodocus Crull (Indianapolis, IN: Liberty Fund, 2002); Christian Thomasius, Essays on Church, State, and Politics, ed. Ian Hunter, Thomas Ahnert, and Frank Grunert (Indianapolis, IN: Liberty Fund, 2007). See also Döring, 'Der Westfälische Frieden', $361-364$.

31 Stolleis, Geschichte des öffentlichen Rechts, vol. 1, 273-275; T.J. Hochstrasser, Natural Law Theories in the Early Enlightenment (Cambridge: Cambridge University Press, 2000), 108. This applies less to the 'Christian natural lawyers': see Hans-Peter Schneider, Justitia universalis. Quellenstudien zur Geschichte des 'Christlichen Naturrechts' bei Gottfried Wilhelm Leibniz (Frankfurt a. M.: Vittorio Klostermann, 1967).

32 Renatus Karl von Senkenberg, Darstellung des Osnabrück- und Münsterischen oder sogenannten Westfälischen Friedens, nach der Ordnung der Artikel (Frankfurt am Main: Gebhard und Körber, 1804); Gérard Laudin, 'Le Gründlicher Discours über den Westfälischen Frieden de Nicolaus Hieronymus Gundling,' in De la guerre juste à la paix juste: Aspects confessionnels de la construction de la paix dans l'espace franco-allemand (XVIe-XXe siècle), ed. Jean-Paul Cahn, Françoise Knopper, and Anne-Marie Saint-Gille (Villeneuve d'Ascq: Presses Univ. du Septentrion, 2008), 136-137. I am grateful to Prof. Anuschka Tischer for pointing out this article to me.

33 By the early eighteenth century, examples of such expulsions, while legal according to IPO, nevertheless caused public outrage across the Empire and Europe. For the example of the expulsion of the Salzburg Protestants, see Andrew C. Thompson, Britain, Hanover and the Protestant Interest, 1688-1756 (Woodbridge: Boydell Press, 2006), 152-167. 
Peace of Westphalia the Empire has not had the audacity to attempt to prevent individual Imperial Estates from tolerating other religions and sects. ${ }^{34}$

Apart from the implications of the external guarantee (see below), there was also some criticism among writers, of various legal and intellectual traditions, of the supposed opacity of many aspects of the treaties, although some believed that was deliberate, in order to facilitate adaptations to conditions in later periods, given that the Peace was proclaimed to be valid in perpetuity. ${ }^{35}$ Indeed, some authors explicitly declared that it was necessary to continually re-interpret the Peace in line with shifting circumstances, and that the ambiguities of the treaties permitted this. ${ }^{36}$ An area of disagreement surrounding the Peace related to differing interpretations of its specific role in the mutual protection of individual and corporate rights, which, along with common defence, was arguably the raison dêtre of the Empire. ${ }^{37}$ According to many writers of natural law, Westphalia chiefly enshrined the corporate rights of the Imperial Estates, whereas writers of the jus publicum generally emphasized the importance of upholding the corporate rights of mediate subjects, i.e. territorial estates and other subjects. They therefore placed greater emphasis on Westphalia's role in safeguarding individual rights of subjects, as well as its role in regulating and strengthening the broader Imperial structure as a restraint against princely absolutism in defence of mediate subjects. ${ }^{38}$

34 Senkenberg, Darstellung, 146.: 'ob diese Verordnung noch gelte? Ich antworte: möchten doch alle, die viele dem Naturrecht so sehr zuwider lauffende Verordnungen des W. Fr. so wenig gelten wie diese! Sie zwar noch nirgends ausdrücklich abgeschafft, aber man hat doch seit dem W. Fr. von Seite des ganzen Reichs einzelnen Reichsständen, nichts in den Weg zu legen sich unterstanden, wann Sie in ihren Landen andere Religionen und Sekten [...] zu toleriren, für gut befunden'. This is not entirely correct though. For an example of an Imperial prince being fined by the judicial tribunals of the Empire for tolerating sects, see Heinhard Steiger, 'Die Gewährung der Gewissensfreiheit durch Ernst Casimir von Ysenburg-Büdingen im Jahre 1712,' in Festschrift für Walter Mallmann, ed. Otto Triffterer and Friedrich von Zezschwitz (Baden-Baden: Nomos, 1978), 293-318. See also Kremer, Westfälischer Friede, 132-152.

35 Kremer, Westfälischer Friede, 3.

36 Johann Friedrich Vetter, Rechtliches Bedenken über drey wichtige, die Religions-Freyheit in dem Heiligen Römisch-Teutschen Reiche betreffende, Fragen; Aus dem Instrumento Pacis Westphalicae, und zwar dessen V. und VII. Articul, erwiesen u. abgefasset (Wetzlar: Nikolaus Ludwig Winkler, 1752), prologue.

37 Peter H.Wilson, War, State and Society in Württemberg, 1677-1 793 (Cambridge:Cambridge University Press, 1995), 19; idem., The Holy Roman Empire. A Thousand Years of Europe's History (London: Penguin Books, 2016), passim.

38 Johann Jacob Moser, Neues Deutsches Staatsrecht, 14: 257-258, 263-264; Johann Stephan Pütter, Historische Entwicklung der heutigen Staatsverfassung des teutschen Reiches, vol. 3 (Göttingen: Vandenhoeck, 1788), 234-239; Karl Friedrich Häberlin, Handbuch des Teutschen Staatsrechts, vol. 3 (Berlin: Vieweg, 1797), 423-425. 
For the natural law writers who advocated a maximum degree of state authority on the level of the territories, a perspective also shared by writers in the tradition of jus publicum universale, such as Justus Henning Böhmer, ${ }^{39}$ the Peace was advantageous and progressive for precisely the same - albeit largely mythical - reasons that the kleindeutsch nationalist historians of the nineteenth century reprobated it: the supposed sovereignty (or, approximate sovereignty) of the German princes. Paradoxically, this was also at the heart of an unwelcome effect of the Peace, which was sometimes commented upon, namely the effects it had on the disunity of the Empire. ${ }^{40}$ It was the same argument of princely quasi-sovereignty supposedly derived from Westphalia which led Friedrich Karl von Moser, rather exceptionally among constitutional jurists of the later Empire, to provide a markedly negative interpretation of the effects of the Peace of Westphalia. As a champion of subjects' rights against princely despotism, the younger Moser was well known for his crusades against the tyrannical tendencies of some of the German princes. In an example of the early mythologizing of Westphalia mentioned above, Moser argued that the effects of Westphalia were regrettable because they greatly empowered the princes and thereby weakened the subjects, by extending the former's authority and prerogatives. ${ }^{41}$ Commenting on 'the increasingly arbitrary power of the princes and lords over their largely very pathetic subjects', he wrote in 1761 that 'the Peace of Westphalia and the Imperial capitulations of election are [...] the foundation of the greatness of the princes, but simultaneously also of the misfortune of their subjects. ${ }^{2}$

39 Justus Henning Böhmer, Introductio in jus publicum universale, ex genuinis juris naturae principiis deductum (Halae Magdeburgicae: Orphanotropheum, 1710).

$40 \quad$ Hermann Conring, De pace perpetua inter Imperii Germanici Ordines religione dissidentes servanda Libelli Duo (Helmstedt: Mullerus, 1657), prologue; Samuel Pufendorf, The Present State of Germany, ed. Michael J. Seidler, transl. Edmund Bohun (Indianapolis, IN: Liberty Fund, 2007), 205-206; Johann Jacob Schmauss, Kurtzer Begriff der ReichsHistorie, in diner accuraten chronologischen Ordnung (Leipzig: Verlag Johann Ludwig Gleditsch, 1720), 689-721.

41 Such arguments made their way into twentieth-century historians' assessments of the state-focussed and authoritarian nature of conceptions of 'German Liberties': Leonard Krieger, The German Idea of Freedom: History of a Political Tradition (Chicago, IL: University of Chicago Press, 1957), 5-7. More recently, Georg Schmidt has provided a corrective to this portrayal: Georg Schmidt, 'Die Idee “deutsche Freiheit”: Eine Leitvorstellung der politischen Kultur des Alten Reiches,' in Kollektive Freiheitsvorstellungen im frühneuzeitlichen Europa (1400-1850), ed. Georg Schmidt, Martin v. Gelderen, and Christopher Smigula (Frankfurt am Main: Peter Lang, 2006), 159-189.

42 Friedrich Karl von Moser, Beherzigungen (Frankfurt am Main: Verlag der Knoch- und Esslingerschen Buchhandlung, 1762), 586: ‘[...] der zunehmenden willkührlichen Gewalt der Fürsten und Herren über ihre größten Theils sehr bedauerns-würdige 
But such debates and criticisms should not detract from the fact that there was general agreement in this period that the treaties were a boon overall, in that they had successfully settled, in a more or less satisfactory manner, all of the main areas of conflict contributing to the Thirty Years' War. ${ }^{43}$ Apart from some Catholic commentators, ${ }^{44}$ there was no principled rejection of the overall legitimacy of Westphalia, a view that predominated in the nineteenth century. Particularly among Protestants, it was viewed as a laudable milestone which secured the rights of their confession and safeguarded peaceful co-existence, while also confirming princely prerogatives and therefore 'German liberties'. It was seen by jurists of public law, such as Johann Jacob Moser and Johann Stephan Pütter, as the most important constitutional law of a praiseworthy legal-political structure of the Empire. ${ }^{45}$ Johann Jacob Schmauss, a professor of history and the law of nature and nations at Göttingen, wrote in 1766 that 'the Peace of Westphalia is the bond which upholds the calm of the German Empire and the friendship between Catholics and Protestants.46 The historian and jurist Johann Ehrenfried Zschackwitz described the Peace as 'the fundamental pillar of the well-being of the German state', although he recognized that it did not succeed in overcoming confessional tensions, which were again increasing at the time he was writing. ${ }^{47}$ He later referred to Westphalia not only as the most important fundamental law of the Empire, but also as the 'guiding star' of its governance. ${ }^{48}$ Several commentators, such as Gundling, routinely described Westphalia as the 'palladium' of the Empire. ${ }^{49} \mathrm{He}$ was not alone in believing that Westphalia formed the basis

Unterthanen [...] Der Westphälische Frieden und die Kaiserliche Wahl-Capitulationen seynd der Grund [...] zu der Größe der Fürsten, zugleich aber auch der Grund von dem Unglück ihrer Unterthanen'.

43 The highly positive assessment of the Peace in Zedler's encyclopaedia entry of 1748 exemplifies this attitude at the time of Westphalia's 1ooth anniversary: Johann Heinrich Zedler, Grosses vollständiges Universal-Lexicon aller Wissenschafften und Künste, vol. 55 (Halle and Leipzig: J.H. Zedler, 1748), 932-936.

44 Kremer, Westfälischer Friede, 1.

45 Pütter, Historische Entwicklung der heutigen Staatsverfassung des Teutschen Reiches, 3: passim; Johann Moser, Neues teutsches Staatsrecht, 1: passim.

46 Johann Jacob Schmauss, Academische Reden und Vorlesungen über das teutsche Staatsrecht (Lemgo: Meyersche Buchhandlung, 1766), 24: 'Der Westphälische Friede ist das Band, wodurch die Ruhe des teutschen Reichs und die Freundschaft zwischen Catholischen und Protestanten aufrecht erhalten wird'.

47 Johann Ehrenfried Zschackwitz, Einleitung zu dem Teutschen Jure Publico, oder StaatsRechte (Leipzig: J.F. Braun, 1710), 96-98.

48 Johann Ehrenfried Zschackwitz, Geschichtsmäßige und in der Reichspraxi gegründete Erläuterung des westfälsichen Friedens (Halle, 1741), 2.

49 Nicolaus Hieronymus Gundling, Gründlicher Discours über den Westphälischen Frieden (Frankfurt and Leipzig: W.L. Spring, 1736), 6. 
not only of a German Imperial order, but also of a European international order. Similar views were held by Heinrich von Cocceji, a professor of the law of nature and nations at Heidelberg, as well as writers who expounded the positive European law of nations based on treaties, such as the Abbé de Mably, although not everyone agreed with this. ${ }^{50}$ Jean-Jacques Rousseau famously regarded the treaties of Westphalia as the basis of the European political system and argued that preservation of the order it had created for the Empire was crucial for the maintenance of the wider balance of power in Europe. ${ }^{51}$

Whether or not Westphalia was seen as the foundation of a broader European order, many writers did grasp the crucial significance of the treaties for the development of international law. The inclusion of the IPO and IPM in published collections of treaties and the popularity of compendia of original sources related to the congress of Westphalia in the early eighteenth century to some extent reflects this. ${ }^{52}$ Zschackwitz considered the securing of the peace through a mutual guarantee of contracting parties particularly noteworthy, while others commented that the multilateral congress at Westphalia was an influential model for subsequent peace-making. ${ }^{53}$ Gerstlacher argued that it was the combination of constitutional law and the law of nations that made Westphalia unique and so important. ${ }^{54}$

In light of this immense significance accorded to Westphalia by all writers, it is unsurprising that many natural law authors viewed it as a constitutional order that needed to be defended, and several writers, such as Pufendorf and Leibniz, placed it at the heart of their reform plans for the Holy Roman

50 Heinrich von Cocceji, Juris Publici Prudentia Compendio exhibita (Frankfurt am Main: J. Schrey \& Heredum H.J. Meyeri, 1695), 8-6o.

$5^{1}$ Jean-Jacques Rousseau, The Political Writings, ed. Charles E. Vaughan (Cambridge: Cambridge University Press, 1915), vol. 2, 372: 'Malgré les défauts de cette constitution de l'Empire, il est certain que, tant qu'elle subsistera, jamais l'équilibre de l'Europe ne sera rompu, qu'aucun potentate n'aura à craindre d'être détrôné par un autre, et que le traité de Westphalie sera peut-être à jamais parmi nous la base du système politique. Ainsi le droit public, que les Allemands étudient avec tant de soin, est encore plus important qu'ils ne pensent, et n'est pas seulement le droit public germanique, mais, à certains égards, celui de toute l'Europe'.

$5^{2}$ Benjamin Durst, Archive des Völkerrechts: Gedruckte Sammlungen europäischer Mächteverträge in der frühen Neuzeit (Berlin: De Gruyter Oldenbourg, 2016); Antje Ochsmann, 'Johann Gottfried von Meiern und die "Acta pacis Westphalicae publica", in Der Westfälische Friede, ed. Duchhardt, 779-803.

53 Zschackwitz, Einleitung zu dem Teutschen Jure Publico, 99; Gottfried Ferdinand von Buckisch und Loewenfels, Observationes Historico-Politicae in Instrumentum Pacis Osnabrugo-Westphalicum (Frankfurt am Main, Leipzig: J.N. Andreae, 1722).

54 Carl Friedrich Gerstlacher, Corpus Juris Germanici Publici et Privati (Karlsruhe: Schmieder, 1784), 310. 
Empire. ${ }^{55}$ The Abbé de Saint-Pierre went further in the early eighteenth century and saw in the post-Westphalian Holy Roman Empire a model for a perpetual peace in Europe, arguing that European states ought to surrender their sovereignty to an international organization in a fashion somewhat analogous to the Imperial Estates' lack of sovereignty and dependence on the Empire. ${ }^{56}$

\section{$4 \quad$ Interventions and Guarantees in the Law of Nature}

By including the 'foreign crowns' France and Sweden in the mutual guarantee of Westphalia, a right to intervene for the protection of constitutional and religious rights within another state was enshrined in positive treaty law, which was unprecedented in the law of nations. ${ }^{57}$ As Westphalia was a fundamental constitutional law, the guarantee theoretically applied to all manner of legal rights, arrangements and privileges within the rather protean Imperial constitution. Because this extended to a variety of mainly confessional rights enjoyed by subjects, the guarantee of the actual Peace of Westphalia, as opposed to the 'Westphalia' of myth, therefore legalized interventions for the protection of the legal rights of subjects in a foreign state. ${ }^{58}$

55 Michael J. Seidler, 'Introduction,' in Pufendorf, Present State of Germany, xvi, xix. Leibniz supported the elevation of Hanover to the gth electorate on the basis that it would strengthen the Westphalian order by adding a militarily powerful and Protestant prince to the select group of electors. He believed this would improve the political and confessional balance at the heart of Westphalia. He repeated this argument following the conversion of the Saxon elector in 1697: Leibniz, Sämtliche Schriften und Briefe, series IV, vol. 5, xxvii; vol. 5, no. 22; vol. 6, no. 11. For his reform plans see ibid., vol. 1, no.7.

56 Peter Schröder, 'The Holy Roman Empire as a model for Saint-Pierre's Projet pour rendre la paix perpétuelle en Europe,' in The Holy Roman Empire, 1495-1806: A European Perspective, ed. Peter H. Wilson and R.J.W. Evans (Leiden: Brill, 2012), 35-5o.

57 For the use of legal and other argumentation in governments' justifications of interventions in other states' domestic affairs, see Anuschka Tischer, 'Grenzen der Souveränität: Beispiele zur Begründung gewaltsamer Einmischung in "innere Angelegenheiten" in der Frühen Neuzeit,' Historisches Jahrbuch 131 (2011): 41-64.

$5^{8}$ See the following works on the guarantee: Hans Wehberg, 'Die Schieds- und Garantieklausel der Friedensverträge von Münster und Osnabrück,' Die Friedens-Warte 48, no. 6 (1948): 281-289; Heinz Duchhardt, 'Friedenssicherung im Jahrhundert nach dem Westfälischen Frieden,' in Friedenssicherung. Bd. 3: Historische, politikwissenschaftliche und militärische Perspektiven, ed. Manfred Spieker, vol. 3 (Münster: Regensberg, 1989), 11-18; Maria-Elisabeth Brunert, 'Friedenssicherung als Beratungsthema der protestantischen Reichsstände in der Anfangsphase des westfälischen Friedenskongresses,' in Frieden und Friedenssicherung in der Frühen Neuzeit: Das Heilige Römische Reich und Europa ed. Guido Braun and Arno Strohmeyer (Münster: Aschendorff 
The two relevant theoretical components of the Westphalian guarantee were intervention for the protection of another prince's subjects, and safeguards of treaties of peace and alliance. Both topics received attention from natural law theorists. There was a contextual shift in the writings on intervention over the course of the early modern period. Sixteenth-century writers such as Francisco de Vitoria and the Spanish Scholastics discussed the legitimacy of intervention in the context of the European colonization of the New World..$^{59}$ This colonial element was still present in the theories of some seventeenth-century writers, such as Hugo Grotius, and to a lesser extent Pufendorf, but the focus now shifted towards a consideration of interventions within Europe, reflecting a greater concern with the European context by natural law theorists. 60

While Thomas Hobbes argued that such interventions for the protection of another prince's subjects were impermissible, ${ }^{61}$ Grotius was much more accommodating to the notion. Building on previous arguments by Jean Bodin and Alberico Gentili, he argued that sovereign rulers could intervene for the protection of foreign subjects in order to punish egregious violations of the law of nature. Subjects themselves had no right of resistance against their own rulers, and therefore foreign sovereigns were entitled to act defensively on their behalf. Subjects' lack of a right of resistance, sovereignty, and protective intervention therefore reinforced one another. ${ }^{62}$ According to Pufendorf's

Verlag, 2013), 229-258; Guido Braun, 'Die französische Diplomatie und das Problem der Friedenssicherung auf dem Westfälischen Friedenskongress,' in Assecuratio Pacis: Französische Konzeptionen von Friedenssicherung und Friedensgarantie 1648-1815, ed. Guido Braun (Münster: Aschendorff Verlag, 2011), 67-130.

59 William Bain, 'Vitoria: the laws of war, saving the innocent, and the image of God', in Just and Unjust Military Intervention. European Thinkers from Vitoria to Mill, ed. Stefano Recchia and Jennifer M. Welsh (Cambridge: Cambridge University Press, 2013), 70-95; Simone Zurbuchen, 'Eigenes und Fremdes im Völkerrecht der Frühen Neuzeit: Rechtfertigung und Kritik der Unterwerfung der Völker der Neuen Welt', in Völkerrechtsphilosophie der Frühaufklärung, ed. Tilmann Altwickler, Francis Cheneval and Oliver Diggelmann (Tübingen: Mohr Siebeck, 2015), 177-197.

6o Emmanuelle Jouannet, 'Des origines coloniales du droit international: à propos du droit des gens moderne au $18^{\text {ème }}$ siècle', in The Roots of International Law - Les fondements du droit international, ed. Pierre-Marie Dupuy and Vincent Chetail (Leiden: Brill, 2014), 649-671.

61 See Jonathan Havercroft, "Was Westphalia "all that"? Hobbes, Bellarmine, and the norm of non-intervention,' Global Constitutionalism 1, no. 1 (2012): 120-140; Richard Tuck, 'Grotius, Hobbes, and Pufendorf on humanitarian intervention', in Just and Unjust Military Intervention, ed. Recchia and Welsh, 107-110.

62 Christoph Kampmann, 'Das "Westfälische System", die Glorreiche Revolution und die Interventionsproblematik', Historisches Jahrbuch 131 (2011): 65-92, at 69 n. 1 1; G.P. van Nifterik, 'Religious and humanitarian intervention in sixteenth and early seventeenth century legal thought,' in Sovereignty and the Law of Nations (16th-18th Centuries), ed. 
conception of natural law, the right to intervene was more restricted. It could take place only if specifically requested by the oppressed subjects, and only if they had a legal right of resistance according to the constitutional set-up of the target state. ${ }^{63}$ Christian Wolff's conception of natural law was similarly disinclined towards intervention: 'to interfere in the government of another [...] is opposed to the natural liberty of nations'.64 However, Wolff's theory did hypothetically permit collective intervention if it was carried out by a so-called civitas maxima. He conceived of this fictitious body as a commonwealth, or republic, encompassing a series of smaller associations and political units. On contractarian grounds, collective intervention by this overarching body could be legitimate, since the member states were joined to this larger unit and committed themselves to its laws. ${ }^{65}$ It is possible that Wolff was influenced by the Holy Roman Empire in devising this theory, as internal interventions within the Empire, mandated by the supreme judicial tribunals on the Emperor's authority against the component territories (Imperial Estates), was legally possible and occurred frequently. Far from curtailing such internal interventions, Westphalia strengthened them by increasing the scope of the basis upon which interventions could take place (chiefly by adding a catalogue of enshrined confessional rights), and by enhancing the legitimacy of the intervening supreme courts through the imposition of confessional parity onto their personnel composition. ${ }^{66}$ Vattel's conception of intervention was even more restrictive. ${ }^{67}$ According to his theory, the international system should consist of legally equal and politically independent sovereign states, which adhere to

Randall Lesaffer and Georges Macours (Brussels: Peeters Publishers, 2006), 35-6o; Tuck, 'Grotius, Hobbes, and Pufendorf on humanitarian intervention'.

63 Tuck, 'Grotius, Hobbes, and Pufendorf on humanitarian intervention', 110-112.

64 Quoted in Jennifer Pitts, 'Intervention and sovereign equality: legacies of Vattel', in Just and Unjust Military Intervention, ed. Recchia and Welsh, 143. See also Richard Tuck, The Rights of War and Peace: Political Theory and the International Order from Grotius to Kant (Oxford: Oxford University Press, 1999), 189-19o.

65 Pitts, 'Intervention and sovereign equality: legacies of Vattel', 142, 144-145.

66 Brendan Simms, 'A false principle in the Law of Nations': Burke, state sovereignty, [German] liberty, and intervention in the age of Westphalia,' in Humanitarian Intervention: A History, ed. Brendan Simms and D.J.B. Trim (Cambridge: Cambridge University Press, 2011), 92; Michael Geyer, 'Humanitarianism and human rights: A troubled rapport,' in The Emergence of Humanitarian Intervention: Ideas and Practice from the Nineteenth Century to the Present, ed. Fabian Klose (Cambridge: Cambridge University Press, 2016), 31-55; Milton, 'Intervening against tyrannical rule'.

67 Simone Zurbuchen, 'Vattel's "Law of Nations" and the Principle of Non-Intervention', Grotiania 31 (2010): 69-84; idem., 'Emer de Vattel on the Society of Nations and the Political System of Europe', in System, Order, and International Law. The Early History of International Legal Thought from Machiavelli to Hegel, ed. Stefan Kadelbach, Thomas 
the attendant rule of non-intervention in each other's domestic affairs. Intervention was allowed only under extraordinary conditions, such as to aid tyrannized subjects who appeal for help and who are actually already in a state of revolt, or in the context of a civil war when the state has collapsed into warring factions, in which case the factions have in effect become distinct polities and it is therefore not truly an intervention within a state. ${ }^{68}$

These exceptions on the part of Vattel and Wolff notwithstanding, the fact that theories of natural law and the law of nations appear to become increasingly anti-interventionist after 1648 seems to lend credence to a key aspect of the 'Westphalian system'. However, as Jennifer Pitts and Brendan Simms have pointed out, these theories were an ideal-type normative narrative, rather than an accurate depiction of post-Westphalian state practice. Nor did they accurately reflect the positive European law of nations, at least with regard to the possibility of French and Swedish intervention in the Empire. Pitts has therefore astutely remarked that the 'Westphalian' model of equal, independent sovereign states should more accurately be termed a 'Vatellian' model. ${ }^{69}$

According to Richard Tuck, Pufendorf's restrictive approach to intervention was influenced by his personal experiences of the Thirty Years' War, with its destabilizing foreign interventions, and he was loath to see the carefully constructed arrangements of Westphalia upset by a new round of interventionism. However, Louis XIV's revocation of the edict of Nantes in 1685 led Pufendorf to reconsider his views and he began to argue for a more expansive possibility to intervene in defence of subjects' rights. ${ }^{70}$ Here one can discern a likely influence of Westphalia, and in particular its juridification of intervention and of toleration, on Pufendorf's theory of the law of nations with regard to intervention. According to his theory, intervention was permissible only if the legal basis for it existed, which is exactly what Westphalia furnished for the first time. However, it provided for the possibility only of a one-sided intervention, by the external guarantors France and Sweden into Germany. Faced with the crisis of the expulsion of the French Protestants, Pufendorf expanded his conception of intervention, on the basis of the principles underpinning Westphalian guarantor intervention, by arguing that the Huguenots legally possessed the liberty of religion 'in their own Right', on the basis of the edict of Nantes, just as the three recognized

Kleinlein, and David Roth-Isigkeit (Oxford: Oxford University Press, 2017), 263-281, at $266-267$.

68 Pitts, 'Intervention and sovereign equality: legacies of Vattel,' 146-148; Tuck, The Rights of War and Peace, 193-194.

69 Pitts, 'Intervention and sovereign equality: legacies of Vattel', 134-135; Simms, 'A false principle in the Law of Nations,' 91. 
confessions possessed it on the basis of IPO. ${ }^{71}$ If the adherents of the three recognized confessions in the Empire were denied this right, then the guarantee of Westphalia could be activated, leading eventually to an intervention. Pufendorf was now arguing that an intervention against France was also permissible, on the similar basis of legal rights of toleration being denied in a tyrannical fashion:

A Prince, who troubles his faithful Subjects merely upon the score of Religion, commits a gross Error [...] as for such Princes and States, as have shaken off the Yoke of Popish Slavery, if they seriously reflect, how their fellow-Protestants are persecuted, and in what barbarous manner they are treated, will, questionless [...] take such measures, as may be most convenient for to secure themselves from so imminent a Danger. ${ }^{72}$

Discussions of guarantees of treaties also appeared in the sections of their works which natural law scholars devoted to the law of nations. Here the influence of Westphalia seems not to have been particularly great, as the innovative character of the guarantees of 1648 - the fact that they were mutually guaranteed by the contracting parties themselves and included lower-ranking guarantors, i.e. Imperial Estates - usually did not make its way into the theoretical works. Pufendorf and Wolff both described the older types of guarantees, whereby third parties, usually mediators, or higher-ranking persons such as the Pope, assume the responsibility of a guarantee. Pufendorf wrote 'when a Peace is mutually ratified by each Sovereign Governour [...] it is usual [...] for some others oftentimes, especially amongst the Assistants at the Treaty, to undertake the Guaranty of the same, with Promises of Aid to him who ever is injured by the other'. ${ }^{73}$ Wolff similarly described the guarantee as commonly being taken over by 'a third party'. ${ }^{74}$ Vattel, however, did refer to the possibility of the contracting parties of a peace treaty guaranteeing their own peace reciprocally, in a manner that first occurred at Münster, without however mentioning Westphalia. Possibly influenced by the policies of Louis XIV towards the Empire in the later seventeenth century, Vattel warned that external guarantors cannot execute treaty

71 Simone Zurbuchen, 'Introduction,' in Samuel Pufendorf, The Divine Feudal Law: Or, Covenants with Mankind, Represented, ed. Simone Zurbuchen, transl. Theophilus Dorrington (Indianapolis, IN: Liberty Fund, 2002), xi.

72 Pufendorf, Of the Nature and Qualification of Religion, 120-121.

73 Samuel Pufendorf, The Whole Duty of Man According to the Law of Nature, ed. Ian Hunter and David Saunders, transl. Andrew Tooke (Indianapolis, IN: Liberty Fund, 2003), 244.

74 Christian Wolff, Grundsätze des Natur- und Völckerrechts, worinn alle Verbindlichkeiten und alle Rechte aus der Natur des Menschen in einem beständigen Zusammenhange hergeleitet werden (Halle: Renger, 1754), 837-838. 
terms on their own accord without being called upon by the signatories, "lest, under colour of being a guarantee, a powerful sovereign should render himself the arbiter of the affairs of his neighbours, and pretend to give them laws.' ${ }^{75}$

\section{The Mutual Guarantee of Westphalia in the Law of Nations and International Politics: Perceptions by}

\section{Natural Law and Public Law Writers}

How did natural law and public law writers assess the guarantee as specifically adopted at the Peace of Westphalia, and as applied in the post-1648 period? It is important to note that the geopolitical context of the time of writing was central, as were the personal circumstances of the author. It is also important to recall that the guarantee applied not only to the religious and constitutional stipulations for the Empire and its inhabitants, but also to the various terms that formed the international dimension of the peace treaty between great powers. Indeed, these terms were prominent in discussions of the guarantee during the first few decades after the conclusion of the Peace, a time when German commentators were highly concerned with preventing the Empire being drawn back into ongoing wars.

A key stipulation in this regard was IPM §3, the so-called Assistenzverbot, which prohibited the Austrian Habsburgs from providing any assistance to their Spanish Habsburg cousins in the ongoing Franco-Spanish war (lasting until 1659), and which also exempted the Burgundian circle of the Empire (consisting largely of the Spanish territory of the Southern Netherlands) from the Imperial defensive framework and from the guarantee. Under Cardinal Richelieu's original plan, the French had approached the peace congress with a view towards achieving a 'universal' peace, in other words, a peace treaty that would simultaneously settle all constituent and related conflicts of the Thirty Years' War. When it became clear that the Franco-Spanish war could not be settled at Westphalia, the congress reached a point of crisis and risked dissolving. At this crucial moment, the congress was arguably saved by the efforts of a cross-confessional 'third party' of smaller princes who were willing to compromise, and who propelled the negotiations forward in its final phase, forcing the Emperor to agree to the guarantee and the non-assistance clause. ${ }^{76}$ This provided France with the assurance that it could continue fighting Spain without

\footnotetext{
75 Vattel, Law of Nations, 396.

76 Christoph Kampmann, Europa und das Reich im Dreißigjährigen Krieg (Stuttgart: W. Kohlhammer, 2013), 128-170.
} 
having to face the Emperor as well, and also assured the Protestant princes that France would come to their aid if the Catholics and the Emperor reneged on their religious concessions and resumed confessional depredations.

It was therefore an important instrument both to propel the peace settlement to its conclusion, and to instil a degree of trust in a mutual and reciprocal enforcement mechanism at a time when trust between the contracting parties was lacking. Pufendorf captured this mutual distrust which necessitated a mutual guarantee when he wrote "The Roman Catholicks charge the Protestants, That they have deprived them of a great part of their Wealth and Riches, and they are night and day contriving how they shall recover what they have thus lost, and the other Party are as well resolved to keep what they have got. ${ }^{77}$ Although it is unknown whether he had the Westphalian congress in mind, Gundling grasped the importance of guarantees in his work on the law of nature and nations, by arguing that the existence of a guarantee could instil trust and increase the willingness of warring parties to conclude a peace treaty, noting that it is 'highly necessary to conclude such guarantees, otherwise the stronger will devour the weaker. ${ }^{78} \mathrm{He}$ recognized that the treaty and its guarantee created a pacified security zone for central Europe, and expressed the hope this zone could eventually be expanded to cover all of Christian Europe. ${ }^{79}$

In the post-war years, the above-mentioned 'third party' of smaller princes continued to actively work towards the preservation of the peace on the basis of upholding the guarantee. In forming the cross-confessional 'Rhenish alliance' (1658-1668) together with both France and Sweden but not the Emperor, the message was clear that they considered the latter the biggest threat to their liberties and to peace. Indeed, he resented being prohibited by treaty law from allying with his relatives in Spain, while his own immediate subjects, the Imperial Estates, allied with France and Sweden. The princes' perspectives soon changed with Louis XIV's assumption of personal rule and the advent of his policy of aggressive expansionism towards the Rhine from the late 166os, after which they viewed Emperor Leopold I as a more effective protector. ${ }^{80}$ This context is important in understanding the assessments of the guarantee in this period by commentators such as Pufendorf and Leibniz. Pufendorf's

77 Pufendorf, Present State of Germany, 204.

78 Nicolaus Hieronymus Gundling, Ausführlicher Discours über das Natur-und Völcker-Recht (Frankfurt am Main and Leipzig: Spring, 1747), 333.

79 Laudin, 'Le Gründlicher Discours', 133.

8o Roman Schnur, Der Rheinbund von 1658 in der deutschen Verfassungsgeschichte (Bonn: Röhrscheid, 1955). 
Monzambano first appeared just as this shift was beginning and later editions were published at the height of the Empire's enmity to France.

Leibniz extensively discussed these geopolitical challenges facing Germany in his oeuvre, although his frame of reference was not so much theoretical and philosophical as grounded in historical empirical analysis. ${ }^{81}$ It is therefore hard to determine how or whether his assessments of Westphalia influenced his conceptions of natural law. In the late 166os, Leibniz discusses the question of the duration of the exemption of the Burgundian circle from the Westphalian guarantee as part of the non-assistance clause. This was highly disputed and the text was ambiguous, but it had clear geopolitical implications as it largely covered the Spanish Netherlands, against which Louis XIV had aggressive designs. France argued that the exemption was perpetual, whereas Spain argued that it was exempt only during the Franco-Spanish war that was ongoing at the time of the conclusion of the treaties of Westphalia, and that had ended in 1659. Spain therefore demanded collective Imperial assistance on the basis of the guarantee were it to be attacked in that circle, and indicated that it would not offer financial contributions to the Empire if it was denied this assurance. The issue became salient in 1667 with the French attack on the Spanish Netherlands. Leibniz argued strongly in favour of the duty and the right of the Empire to defend the Spanish Netherlands, and that the guarantee remained exempt only for the duration of the war that was ongoing between France and Spain at the time of the signing of the treaty of Münster. He argued that failing to provide the requested assistance would amount to an abdication of the responsibilities of the guarantee of Westphalia. ${ }^{82}$

Leibniz followed this up with a political tract in 1670 in which he discussed the best means for the Empire to achieve security in light of France's hegemonic designs. ${ }^{83}$ Its primary addressee was the archbishop-elector of Mainz, who had been the chief architect of the Rhenish alliance of 1658. Leibniz considered means to strengthen the defence of the Empire in the face of the

\footnotetext{
81 Wilhelm Schmidt-Biggemann, 'Leibniz,' in Politische Theorien des 1 7. und 1 8.Jahrhunderts: Staat und Politik in Deutschland ed. Bernd Heidenreich and Gerhard Göhler (Darmstadt: Philipp von Zabern, 2011), 149-151.

82 Leibniz, Sämtliche Schriften und Briefe, series IV, vol. 1: 115-130, 141.

83 Bedencken welchergestalt Securitas publica interna et externa und Status praesens im Reich, jitzigen Umständen auf festen Fuss zu stellen (1670), in ibid, pp. 133-214. See also Christoph Kampmann, Arbiter und Friedensstiftung. Die Auseinandersetzung um den politischen Schiedsrichter im Europa der Frühen Neuzeit (Paderborn: Ferdinand Schoeningh, 2011), 220-226, and Wolfgang Burgdorf, Reichskonstitution und Nation. Verfassungsreformprojekte für das Heilige Römische Reich Deutscher Nation im Politischen Schrifttum von 1648 Bis 1806 (Mainz: Philipp von Zabern, 1998), 88-95.
} 
French threat. He believed that Louis XIV did not want to directly conquer the German lands but rather, as had already occurred via the Rhenish alliance, place himself in the position to be the arbiter of conflicts within the Empire and therefore indirectly dominate Germany. However, the solution was not for Mainz or the Emperor to join the triple alliance of England, Sweden and Netherlands. Leibniz considered it 'a particularly dangerous alliance, which France would interpret as a hostile declaration'. Instead, the princes should seek to form a broad-based alliance that was not necessarily reliant on the Emperor, modelled on the Rhenish alliance and designed to secure the Westphalian order, in order to harness the defensive capacity of the Empire: 'the purpose of this alliance should be nothing other than to provide each other the guarantee of the Peace of Westphalia, which all Imperial Estates are bound into anyway'. A broad-based alliance of princes would do little to draw the Empire into foreign wars that did not directly affect its interests, nor would it cause offence or provoke aggression among other powers, primarily France, 'especially because such an alliance amounts to nothing less than the Rhenish alliance which is in accordance with the Peace of Westphalia and the guarantee incorporated therein'.

According to Leibniz, the Westphalian order was very much at the heart of what needed defending and strengthening: 'everyone has an interest in ensuring that the Peace of Westphalia remains active, and all should act together so as to ensure that it is better implemented. ${ }^{84}$ Leibniz argued that France was very adept at using the guarantee as an occasion or pretext to strengthen its position in the Empire and achieve the position of an influential arbiter, or arbitrium rerum, which allowed it to build a strong patronage network and essentially usurp the position of the Emperor as a mediator and adjudicator in inter-territorial disputes. Depending on its own interest, France would take sides against the party that was unwilling to ally with it or to become its client. ${ }^{85}$

Thus, although Leibniz saw the mutual guarantee as a helpful institution that ought to be strengthened, he was acutely cognisant of the dangers

84 Leibniz, Sämtliche Schriften und Briefe vi, 1: 141:: 'ein absonderlich gefährlich Bündnüß, so Franckreich pro declaratione hostilitatis aufnehmen wird'; ibid., 1: 158: 'Der Zweck solcher Allianz soll nichts anders seyn, als blatt und bloß Garantiam Instrumenti Pacis, darinnen ohne das alle stände begriffen, einander zu leisten'; ibid., 1: 140: 'Sind iede insonderheit verbunden daran zu seyn damit das Instrumentum pacis in vigore bleibe, so können sie sich ja dazu mit einander zu beßerer Execution noch mehr verbinden'.

85 Ibid., 1: 193-5. For an analysis of French protection and patronage policy towards the Rhenish ecclesiastical electors, see Tilman Haug, Ungleiche Außenbeziehungen und grenzüberschreitende Patronage. Die französische Krone und die geistlichen Kurfürsten (16481679) (Cologne: Böhlau, 2015). 
emanating from France's instrumentalization of it for Louis XIV's own interests. In the 1680s he accused France of having violated the IPM as the rightful foundation of relations between France and the Empire, and abused its guarantor position with the Reunions policy. ${ }^{86}$ At the time of the Peace of Ryswick, the fourth article of which altered the confessional balance in the Palatinate, Leibniz described the clause in question as a violation and a great blow to the religious terms of Westphalia, 'which are one of the best foundations of peace and calm', but regretted its 'lack of guarantees'. ${ }^{87}$ Westphalia was not seen as ideal by Leibniz, but it was nevertheless to be the basis for an improved system. The above quote shows that he saw the treaty structure as a good internal organizing system as well as the basis of a defensive barrier against France.

Pufendorf's Monzambano appeared in the context of one of the interterritorial disputes mentioned by Leibniz, the Wildfangstreit between the elector-Palatine and a number of its neighbours, in which the former sought assistance from the external guarantors, Sweden and France. ${ }^{88}$ Pufendorf was employed at the elector-Palatine's university of Heidelberg at the time, which might explain why the Swedish intervention in the Thirty Years' War was portrayed in a fairly positive light as having ensured the protection of Protestants from Austrian persecution. ${ }^{89}$ The guarantee itself is not portrayed negatively, although Pufendorf did criticize the princes' right to form alliances (jus foederum), an old customary practice that was enshrined at Westphalia. In combination, the two weakened the unity of the Empire and exposed it to deleterious foreign machinations. Pufendorf considered it a 'pernicious Disorder [...] That the Princes of Germany enter into Leagues, not only one with another, but with Foreign Princes too, and the more securely, because they have reserved to themselves a Liberty to do so in the Treaty of Westphalia'. He believed the jus foederum was dangerous because it 'not only divides the Princes of Germany into Factions', but also because it provides the guarantors, France and Sweden, with an ability to 'mould Germany to their own particular Interest and Wills, and ultimately, when given an appropriate opportunity, by the assistance of their German Allies, to insult on all the rest of the Princes, especially when the

86 Leibniz, Sämtliche Schriften und Briefe, series vi, vol. 2: 471-502.

87 Leibniz, Sämtliche Schriften und Briefe, series I, vol. 14: no. 56: 'welche eine der besten Fundamente des Friedens und der Ruhe sind [...] Mangel an Garantien'; Leibniz, Sämtliche Schriften, series vi, vol. 6: no. 42, 6: 289-297.

88 Roman Schnur, Der Rheinbund von 1658 in der deutschen Verfassungsgeschichte (Bonn: Röhrscheid, 1955), 8o-83.

89 Pufendorf, Present State of Germany, 191. The intervention is portrayed even more positively in his later publications when he was a royal court historian of Sweden: Pufendorf, An Introduction, 519 . 
Design of those Leagues is not levell'd against other Foreign Princes [...] but against the Members of the Empire itself'. Pufendorf therefore suggested that, while retaining Westphalia as a foundation, the members of the Empire must make provision to prevent foreign interference in its affairs and to harness common defence efforts to prevent a loss of territory to foreign conquerors. Amending the jus foederum to prevent princes allying against each other was one such option. ${ }^{90}$ In later editions of the piece, the earlier anti-Habsburg tone was replaced by a strong anti-French sentiment, reflecting the shifting mood outlined above. ${ }^{91}$ Towards the end of his career, Pufendorf accused France of pretending 'to play the Master over Princes' through designs 'which overturn the Westphalian Treaty, or are intended against the Protestants in Germany and Holland'.92

The basic premise of Pufendorf's view of the well-being of Europe was that universal monarchy must be prevented. Westphalia was valuable and laudable in that it represented the culmination of the successful struggle against such attempts by the Habsburgs and, moreover, the achieved balance was mutually guaranteed and therefore secured for the future. Preventing the Holy Roman Empire from being dominated by a single power was vital to undercutting the emergence of universal monarchy. This risk existed both from within the Empire, chiefly through the Habsburgs, and from without, by being subjected to a foreign power's control. Therefore, the mutual guarantee clauses were highly important and effective, as none of the guarantors would permit the other to establish such a domination over Germany. While retaining this basic premise, Pufendorf's assessment of various individual stipulations and the state of the Westphalian order shifted in response to the changing geopolitical context, as well as the interests of his employer. Nevertheless, his writings were always guided by a belief in the necessity of upholding the basic German and international order as established at Westphalia; however, the treaties also contained provisions which themselves threatened to undermine that very order..$^{93}$

In the early 1740 , during a renewed period of French activism and military operations in the Empire (following a period of relative withdrawal in 17141733), Schmauss sought to analyse individual states' self-interests and he argued that France assigned great value to its guarantor status. He wrote that France

90 Pufendorf, Present State of Germany, 205-206, 219-220. See also Peter Schröder, 'The constitution of the Holy Roman Empire after 1648: Samuel Pufendorf's assessment in his Monzambano,' The Historical Journal 42, no. 4 (1999): 970.

91 Pufendorf, Present State of Germany, 193.

92 Pufendorf, An Introduction, 6o2. See also Döring, 'Der Westfälische Frieden', 359-36o.

93 Döring, 'Der Westfälische Frieden', 353-355. 
uses guarantees to enhance its influence without expensive wars of conquest and direct rule. The guarantees allow France to achieve an 'ascendancy and a higher degree of a general direction of Europe [...] The guarantee of the peace of Westphalia gives her a pretext to interfere in German affairs'. The French security apparatus combined this with numerous other guarantees, such as that of Polish liberties and its 'leapfrog diplomacy ${ }^{\prime 94}$ with the Swedes and the Turks. In general, France's use of its guarantor status shows 'that France knows well how to cunningly make use of the guarantee, in order to acquire direction over everything that occurs in Europe'. ${ }^{95}$ Guarantees of peace treaties and other international arrangements were an effective instrument of French hegemony, because 'a guarantee is nothing other than a right to involve oneself in other affairs, by citing one's obligation as a guarantor, if this is deemed to further one's interests. ${ }^{96}$

Other assessments by German jurists and other scholars in the early to mideighteenth century were similarly critical of France's use of its guarantee, without necessarily denying the theoretical value of the institution as a method to secure the peace. Like Pufendorf, Johann David Köhler and Franz Dominicus Häberlin viewed the jus foederum as dangerous, especially in combination with the French guarantee. They believed that the liberties granted to the princes were excessive, weakened the Empire as a whole, and helped France gain ascendancy over Germany, primarily through the guarantee. France's previous intervention in the Thirty Years' War was argued to have been designed purely to serve its own geopolitical interests, with Teutsche Freiheit employed as a blind to cover its own naked ambitions. ${ }^{97}$ In determining the reception of the

94 Brendan Simms, 'Europe's shifting balance of power,' in The Oxford Handbook of Early Modern European History, 1350-1750, Vol 2: Culture and Power, ed. Hamish Scott (Oxford: Oxford University Press, 2015), 649-65o.

95 Johann Jacob Schmauss, Einleitung zu der Staats-Wissenschafft, und Erleuterung Des von ihm herausgegebenen Corporis Juris Gentium Academici und aller andern seit mehr als zweyen Seculis her geschlossenen Bündnisse, Friedens- und Commercien-Tractaten, vol. 1 (Leipzig, 1741), 63o.: 'Ascendant, und höhern Grad einer allgemeinen Direction in Europa [...] Die Garantie des Westphaelischen Friedens giebt ihm Vorwand, sich in Teutsche Sachen zu Mengen ... daß sich Frankckreich der Garantie gar listig zu bedienen weiß, um sich [...] über alles und iedes was nur in Europa vorgehet eine Direction zu erwerben'.

96 Ibid., 631: 'Eine Garantie ist nichts anders, als ein Recht, sich unter Anführung der Obliegenheit eines Garant in andere Händel zu mischen, wann man es seinem Interesse gemäß erachtet'.

97 Johann David Köhler, Kurtzgefaste und gründliche teutsche Reichs-Historie (Frankfurt and Leipzig: Riegel, 1736), 564-566; Franz Dominicus Häberlin, Anmerkungen über die in Johann Carl Königs Selectorum juris publ. P. VIII. c. 1 6. befindliche Erörterung der Frage: Ob die Crone Frankreich vor einen Erbfeind des H. R. Reichs zu achten seye? (n.p., 1745), passim. 
guarantee among legal and political writers of the period, one ought to be clear about the purpose of the author. One must distinguish between assessments of the guarantee as it operated in geopolitical and diplomatic practice on the one hand, in other words its role in Franco-German and Swedish-German relations, and how it was evaluated as an instrument under the law of nations on the other hand. This distinction is more significant than locating the author in a particular tradition such as natural law or public law, although individual writers often addressed both aspects in the same publications. The commentaries in the works examined so far have mainly been of the former category, namely assessments of the role and effects of the guarantee in practice. When assessed in principle, the guarantee was viewed much more positively, especially in the later eighteenth century, during a period of French decline far removed from the hegemonic wars of Louis XIV. Johann Stephan Pütter, for example, lauded the guarantee as 'highly praiseworthy' 98 The Halle professor Johann Christian Krause viewed the guarantee as beneficial in theory and in practice, as it promoted the unity of Europe by tying numerous powers into a reciprocal system of securing the peace. ${ }^{99}$ Mably argued that the mutual guarantee elevated Westphalia above other peace treaties because it encompassed carefully devised mechanisms to provide long-term safeguards of the peace. ${ }^{100}$

The prolific scholar of public law Johann Jacob Moser was one of the few jurists to write a monograph specifically on the guarantee of Westphalia. ${ }^{101}$ It was primarily a legal exposition of the guarantee in theory, although it also served a contemporary political purpose, namely to define a set of parameters in order to limit the ways in which the guarantee could be applied in practice, otherwise the external guarantors could plausibly assert a right to intervene in any matter affecting the Imperial constitution. ${ }^{102}$ Moser's aim was undoubtedly influenced by more than a century of French instrumentalization of the guarantee for power-political ends. ${ }^{103} \mathrm{He}$ did this by insisting that the guarantee could be activated and implemented by armed force only if it was requested by the injured party, and only if all other internal Imperial judicial channels

98 Johann Stephan Pütter, Der Geist des Westfälischen Friedens; nach dem Buchstaben und Sinn desselbigen (Göttingen: Vandenhoeck und Ruprecht, 1795), 543.

99 Johann Christoph Krause, Lehrbuch der Geschichte des Dreyßigjährigen teutschen Krieges und Westphälischen Friedens (Halle: Johann Christian Hedel, 1782), 130.

100 Gabriel Bonnot de Mably, Le droit public de l'Europe, fondé sur les traités (Amsterdam: Arkstee \& Merkus, 1761), 8-10.

101 Johann Jacob Moser, Von der Garantie des Westphaelischen Friedens; nach dem Buchstaben und Sinn desselbigen ([Stuttgart], 1767). See also Kremer, Westfälischer Friede, 44-46.

102 Moser, Von der Garantie, 44.

103 Moser, Neues teutsches Staatsrecht, 1: 45o. 
had been exhausted without procuring redress. In exercising the guarantee, the guarantors must comply with natural law and the law of nations. Although the Emperor was himself a guarantor as well, Moser argued that the exercise of his guarantee must not allow him to arrogate to himself rights as a guarantor derived from the law of nations which were denied him as head of the Empire on the basis of Imperial constitutional law. Therefore, jus publicum set limits to his freedom of action as derived from jus gentium. Moser also emphasized that the guarantee was designed to uphold not only princely rights, but also those of the 'mediate members of the Empire, territorial estates and subjects'. ${ }^{104}$ This was the case because 'In so far as much of the Peace of Westphalia is provided for their benefit, it applies to them as interested parties of the Peace; and just as the Peace itself, this is also the case with its guarantee, according to which one can and must take up their cause, if they are affronted in violation of the Peace.'105

Moser was thus one of the few scholars who discussed the guarantee in terms of its potential role as a legalized form of intervention for the protection of foreign subjects. ${ }^{106}$ When addressing the question of who could be targeted in an intervention according to the guarantee, Moser wrote that anyone violating the terms of the Peace was a legitimate target, including the Emperor, an external power and the territorial princes. ${ }^{107}$ Moser stressed that the guarantee did not render the Imperial judiciary obsolete in the securing and executing of the Peace. Instead, he viewed the guarantee as its substitute, to be resorted to only if the regular channels failed to enforce Westphalian rights:

This armed guarantee should be a surrogate for the judicial office, and the guarantors should be authorized to take those measures which the judge, under whose jurisdiction the complainant is, should have taken, but did not take, either because he was not appealed to, or because he hesitated

\footnotetext{
104 Moser, Von der Garantie, 46: 'mittelbare Glieder des Reichs, Land=Stände und Unterthanen'.

105 Ibid.: 'In so ferne aber viles in dem Westphälischen Friden zu ihrem Besten verordnet ist, seynd sie Fridens=Intereßenten, und wie des Fridens selbst, also auch dessen Garantie, in so fern fähig, daß man sich ihrer annehmen kan und muß, wann sie gegen den Fridens=Schluß beleidiget werden'.

106 An actual example of the implementation of the guarantee for the protection of foreign subjects (albeit not strictly following the prescribed steps) was Sweden's intervention for the benefit of the Protestants of Austrian Silesia in 1707. See Norbert Conrads, Die Durchführung der Altranstädter Konvention in Schlesien 1707-1709 (Cologne: Böhlau, 1971).

107 Moser, Von der Garantie, 47.
} 
for too long. Hence the external guarantors, who otherwise have no jurisdiction in this state, may nevertheless intervene in such cases. ${ }^{108}$

While Moser generally sought to restrict the practical application of the guarantee by the foreign powers (instead pointing to the internal guarantors as being more promising), he did seek to make it more impactful in one important respect. He argued that the three-year waiting period stipulated by the treaty before a guarantor intervention could take place was excessive and should therefore be ignored, because in urgent cases the injured party might incur unacceptable losses if rapid redress were not forthcoming. ${ }^{109}$ He was making the case for adhering to the spirit rather than the letter of the law, as the title of his monograph indicated.

Another author who devoted a work to the guarantee was the professor of public law Johann Christoph Steck, who penned his essay on instructions from Brandenburg-Prussia in $1757 .{ }^{110}$ The geopolitical context was the recent activation of the guarantee by all guarantors, France, Sweden, the Emperor and the Empire, against Prussia for having invaded and laid waste to Saxony at the outset of the Seven Years' War (1756-1763). It is notable that despite the wartime interests of his employer of having this example portrayed as an abuse of the guarantee, given that it was directed against Berlin, the author nevertheless highlights the benefits of the mutual guarantee in theory and when properly applied. In general, he held the Peace of Westphalia in very high regard, as it safeguarded and enshrined Protestant and princely rights, and he portrayed the mutual guarantee as a necessary, effective, and appropriate new instrument in international law to secure the longevity of the peace terms: 'no more effective means to eternalize this Peace and to secure its holiness could have been devised than the guarantee and warranty, which all contracting powers have reciprocally assumed over it'.111 Older means of securing the peace, such

108 Ibid., 64: 'Dise gewaffnete Garantie solle ein Surrogatum des richterlichen Amtes seyn, und die Garants sollen befugt seyn, das zu thun, was der Richter, unter dem der Beleidigte stehet, hätte thun sollen, aber nicht gethan hat, weil er entweder nicht angeruffen worden ist, oder zu lang gezaudert hat, dahero die auswärtige Garants, denen sonsten in solchem Staat keine Gerichtbarkeit zustehet, in solchem Fall dennoch zugreiffen dörffen'.

109 Ibid., 49, 57.

110 Johann Christoph Wilhelm Steck, 'Abhandlung von den Rechten und Pflichten der hohen Garans des Westphälischen Friedens,' in Abhandlungen aus dem deutschen Staats- und Lehnrecht zur Erläuterung einiger neuen Reichsangelegenheiten (Halle: Johann Justinus Gebauer, 1757), 99-132.

111 Ibid., 103.: 'Kein wirksameres Mittel aber konte ausgesonnen werden, diesen Frieden zu verewigen, und seine Heiligkeit zu versichern, als die Garantie und Gewährleistung welche alle schließende Mächte wechselweise darüber übernommen haben'. 
as the exchange of oaths and hostages, 'had long ago ceased to be adequate in instilling loyalty and faith in treaties between nations.'12 ${ }^{112}$ The guarantee was effective precisely because self-interest and suspicion about the other side's future adherence to the agreement prevailed. Not all parties were believed to have had an equal desire to see Westphalian terms upheld, particularly the Emperor, who lost entire provinces and saw his plans for an 'unlimited power over Germany' scuppered, while also being highly suspicious of Sweden's new role as an Imperial Estate with considerable territories in north Germany. It was therefore 'highly necessary to employ great care and guidance, to make this peace perpetual and binding'. In pursuit of this goal, 'all diligence would have been futile, if all contracting powers had not committed themselves to reciprocally safeguard the holiness and compliance with this Peace, and to offer each other powerful assistance against any violator.'13

Steck argued that one needed to distinguish between the internal and the external guarantors, because 'our Peace is a treaty between European powers, and simultaneously a fundamental constitutional law of the German Empire.'114 The external guarantors did have certain rights and duties which Steck saw as grounded in natural law. Citing Wolff's and Cocceji's work on jus gentium et naturae, ${ }^{115}$ Steck argued that guarantors were obliged to ensure that treaty terms are upheld and to remonstrate, and if need be act against violators of the guaranteed treaty, if called upon to do so by the injured party. Steck then applied this to the Westphalian guarantors and stated that Sweden and France were empowered to ensure the maintenance and upkeep of the terms of Westphalia and the Imperial constitution in general. They were authorized to defend the constitutional and fundamental laws of the Empire, to intervene on behalf of and for the protection of those whose Westphalian rights had been violated, 'to guard the freedom of the Imperial Estates', to interfere in Imperial business as long as called upon by the injured party, and to defend

112 Ibid.: 'längstens nicht mehr hinreichend Treue und Glauben in den Bündnissen der Völcker zu befestigen'.

113 Ibid., 104-105: 'unumschränkten Gewalt über Teutschland [...] höchstnöthig, alle Maasregeln der Vorsichtigkeit zu ergreifen, und diesen Frieden dauerhaft und seine Verbindlichkeit unauflöslich zu machen [...] Alle Behutsamkeit aber würde vergeblich gewesen sein, wenn sich nicht alle schließenden Mächte wechselsweise verpflichtet hätten, über der Heiligkeit und Beobachtung dieses Friedens zu wachen, und sich wider alle Übertreter desselben kräftigen Beistand zu leisten'.

114 Ibid., 107:'unser Friede ein Bündnis Europäischer Mächten, und zugleich ein Grundgesetz des deutschen Reiches ist'.

115 The works cited are Christian Wolff, Jus gentium methodo scientifica pertractatum (Halle: Renger, 1749), chap. IV, §§ 443-445, 363-364; Heinrich v. Cocceji, Disputatio juris gentium publici de guarantia pacis (np, 1702), vol. 1, diss. 4 . 
the confessional rights of the three recognized confessions. This broad scope made the dangers of potential abuse and exploitation particularly large, although Steck did not deny that the external guarantors had a right and duty to intervene in the internal affairs of the Empire only if Westphalian terms were actually violated, and only if they were called upon by the injured party beforehand. ${ }^{116}$ Given the political aims he pursued, Steck argued that France had indeed abused the guarantee for its own self-interest, as was the case in 1756/ 1757. Steck submitted that Prussia was in fact defending Westphalian rights by acting defensively against a planned dismemberment through pre-emption in order to defend the principle of Imperial Estates being allowed to retain the territories whose possession had been confirmed at Westphalia. He suggested that more emphasis needed to be placed on the internal guarantors to defend the terms of Westphalia that dealt with arrangements within the Empire and the Imperial constitution in general. ${ }^{117}$

The exercise of the guarantee by the internal guarantors, which Steck and Moser both viewed as more beneficial to the Empire's interests than the external guarantee, was not uncontroversial either. It had been at the heart of a constitutional crisis that emerged in the early eighteenth century at a time of renewed confessional strife occasioned by several restrictions imposed on Protestant subjects by the electors of the Palatinate and Mainz, and several smaller Catholic princes along the Rhine. The umbrella organization of Reichstag envoys representing all Protestant Imperial Estates, the Corpus Evangelicorum, used this crisis and the publicity campaign surrounding it to assert a new interpretation of the guarantee of Westphalia. In the 1710 and 1720 s the Corpus developed a constitutional vision which asserted that, as contracting parties of the treaties of Westphalia, the Protestant princes were entitled on the basis of the guarantee to execute the treaty terms by force if necessary, if Westphalian terms were violated and if the Emperor refused to immediately dispatch execution commissions. The Corpus was therefore asserting a right to intervene in the domestic territorial affairs of Catholic princes for the protection of the latter's Protestant subjects. It claimed to derive this right not only from the positive law of the Westphalian guarantee, but also from the right, based in natural law, of corporate groups proffering assistance to fellow members. ${ }^{118}$

116 Ibid., 114-115: 'Vor die Freyheit der Reichsstande zu wachen'.

117 Ibid., 118-119, 122-124.

118 See Patrick Milton, 'The early eighteenth-century German confessional crisis: the juridification of religious conflict in the re-confessionalised politics of the Holy Roman Empire,' Central European History 49 (2016): 39-68. 
The Protestant diplomats at Regensburg received ample intellectual support in this endeavour from several of their co-religionists in the field of public law and natural law. While the Emperor and the Catholics rejected this expanded scope of legally buttressed interventions for the protection of other princes' subjects, Protestant jurists largely espoused the Corpus's pluralistic interpretation of protective intervention, based on Westphalia and general invocations of natural law. ${ }^{119}$ Moser, the most vociferous advocate of this expanded authority of intervention conceived as self-help, answered the question of 'Whether [...] Imperial Estates of either religion are permitted to step in and support fellow estates of their own religion, as well as co-religionists who are subject to the territorial rule of other Imperial Estates', with an emphatic yes. ${ }^{120} \mathrm{He}$ was also of the opinion that individual princes or corporate unions such as the Corpus Evangelicorum had the right 'to resort to more forceful and finally violent measures, when amicable means have been fruitless, and when the confessional grievances have multiplied.121 Furthermore, Moser commented 'that in the entire text of the Treaties of Westphalia there is not a single passage which states that Protestants should necessarily be obliged to refer only their confessional grievances to the Emperor, and to await only his verdict and assistance in such matters'. The only exception to this right had been made for the Austrian hereditary lands. ${ }^{122} \mathrm{He}$ stressed that 'there can be no doubt that customary protective justice [...] and art. 17 Pac. Westph. § 5, 6 \&c grants all contracting parties an undeniable right to uphold all and every stipulation of the said Peace, and to protect everyone for whose benefit the terms were stipulated [...] those terms of the 5 th article which stipulate subjects' religious and

119 Steck supported this interpretation of the guarantee: Steck, 'Abhandlung von den Rechten', 132. See also Nicolaus Hieronymus Gundling, Ausführlicher Discours über das Natur- und Völcker-Recht, 332, and the references cited in the published appeal by the Corpus Evangelicorum to the Emperor's representative (Prinzipalkommissar) at the Imperial Diet, Regensburg, 28 Dec. 1719, in Europäische Staats-Cantzley, ed. Anton Faber (Frankfurt a. M. and Leipzig, 1697-1760), vol. 35 (1720), 381-439.

120 Moser, Neues teutsches Staatsrecht, vol. 7: 208: 'Ob [...] der einen oder anderen Religion zugethanen Reichs=Ständen erlaubt seye, sich ihrer Religionsverwandten Mitstände, wir auch ihrer unter anderer Reichsstände Landeshoheit stehenden Glaubensgenossen, anzunehmen?'.

121 Ibid. 254: 'wann die gütliche Mittel nichts haben verfangen wollen, und die Religions=Beschwerden [...] gehäuffet worden seynd, nachdrücklichere und endlich gewaltsame Wege zu ergreiffen'.

122 Ibid. 426-427: 'Es ist aber höchst=merckwürdig, daß in dem ganzen Instrumento Pacis kein Wort zu befinden ist, daß die Evangelischen schuldig seyn sollten, ihre Religionsbeschwerden nothwendig bey dem Kayser anzubringen, und alleine Dessen Auspruch und Hülffe darüber zu erwarten'. 
church rights are by no means excluded therefrom.123 It was in this context of the internal exercise of the guarantee for the protection of Protestant subjects' Westphalian confessional rights that Moser called for the disregarding of the three-year waiting period. Gundling also supported the Corpus's interpretation of its right to intervene on the basis of his natural law conception of guarantees in the international sphere, although not on the basis of a right to intervene for the protection of a foreign ruler's subjects whose rights are being violated.124

\section{Conclusion}

This chapter has attempted to demonstrate that assessments of Westphalia among jurists varied considerably depending on the particular aspect of the settlement that was being written about, as well as the context and period in which its later impact was being evaluated. Contrary to the claims of the Westphalian myth, the Peace increased the legal scope of external involvement in the Empire and its individual territories, by providing for (and in the case of internal Imperial interventions, strengthening) a juridification of intervention. This new development in international and constitutional law furnished legal thinkers with much food for thought. Among writers of the natural law tradition, there was a distinct ambivalence towards the guarantee and foreign intervention in the Empire in general, especially on the part of seventeenthcentury and early-eighteenth-century scholars. The experience of the Thirty Years' War had undoubtedly been traumatic and the foreign interventions had greatly exacerbated the suffering and prolonged the war. However, such writers portrayed the risk of Habsburg monarchical hegemony over the Empire as a threat, and the confessional and princely liberties which were threatened by it could be defended only through foreign assistance. The resulting guarantee legalized this external protection of confessional and political rights, and thereby 'codified' foreign involvement in the Imperial constitution. Yet this state of affairs was largely seen as deleterious in practice, due to French abuse,

123 Ibid., 7:202-203: 'Es lässet sich unter keinem Schein zweifeln, ob nicht [...] von Alters hergebrachten Schuz= und Schirms=Gerechtigkeiten [...] Art 17 Pac Westph $\S 5,6$ \&c den sämtlichen Pacis Consortibus ein unwidersprechliches Recht beygelegt seye, alle und jede Verordnungen selbigen Fridens zu handhaben, und diejenige, denen zu gute sie gemacht sind, dabey zu schützen [...] wovon diejenige hauptsächliche Verordnungen des 5 ten Art welche von der Unterthanen Religions= und Kirchen=Gerechtsamen disponiren, keineswegs auszuschliessen sind'.

124 Nicolaus Hieronymus Gundling, Ausführlicher Discours über das Natur-und Völcker-Recht, 332 . 
and some theorists also saw it as damaging in theory because it arguably weakened the unity of the Empire.

The paradox can be illustrated by Pufendorf's writing on the topic. In his theory of the law of nature and nations, he argued that states are a necessary form of human organization, which allow people to escape from their natural state of insecurity, and therefore to achieve common peace. Yet in order to fulfil these tasks, such states must be of a 'regular' form, with clearly unified sovereignty. ${ }^{125} \mathrm{He}$ famously viewed the Empire as lacking such regularity, ${ }^{126}$ and he regarded the jus foederum and the external guarantee as among the chief reasons for the disunity of the Empire. Yet his modest reform plans for the Empire were firmly grounded in a continuation of the Westphalian order, and he often argued that the liberties of Europe and the Protestant interest required that Germany not be dominated by a single power. In any case, he argued that to re-impose a centralized Imperial monarchy in Germany would exact too high a price in terms of conflict and disorder. ${ }^{127} \mathrm{He}$ also expressed contradictory attitudes towards the foreign interventions in the Empire. On the one hand he viewed the ability of foreign powers to interfere in the Empire as highly deleterious in his Monzambano, yet on the other hand he later portrayed the Swedish intervention of 1632 in particular as having been advantageous and the foreign crowns as having secured German liberties when writing his Introduction to the History of the Principal Kingdoms, which was clearly a reflection of the influence of his personal circumstances.

The influence of the experience of the war and the peace settlement on the conceptions of natural law can be inferred at times, yet more detailed research would be necessary on this topic to achieve a clearer picture. When comparing the writing on the law of nations in the context of the guarantee of Westphalia by authors from the public law tradition and by authors from the natural law tradition, some differences emerge. Several natural law writers argued that interventions for the protection of foreign subjects were permissible in the law of nature and nations, a right which the public law scholars who focussed more on positive treaty law, such as Moser, denied. According to him, such interventions were possible only if explicitly provided for in positive treaty law, as opposed to being permissible in the underlying normative framework of natural law, and it was precisely the guarantee of Westphalia which provided the only permissible form of foreign intervention. It is clear, though,

125 Vattel, Law of Nations, VII.2.13, 8.1-4. Michael Seidler, 'Introduction,' in Pufendorf, Introduction, xxii-xxiii.

126 Pufendorf, Present State of Germany, 159.

127 Ibid., 216. 
that scholars from both a natural law and a public law perspective agreed on the significance of the seminal nature of the peace settlement for the development of the law of nations. ${ }^{128}$

\section{Bibliography}

'Der Festgeschnürte Frieden: Prof. Christoph Kampmann erklärt ein Meisterwerk der Diplomatie,' P.M. History, May 2017.

Achenwall, Gottfried, Geschichte der allgemeineren Europäischen Staatshändel des vorigen und ietzigen Jahrhunderts im Grundriss der europäischen Geschichte (Göttingen: Verlag der Witwe Vandenhoeck, 1761).

Beales, Derek, Joseph II, vol 2: Against the World, 1780-179o (Cambridge: Cambridge University Press, 1987).

Beaulac, Stephane, 'The Westphalian legal orthodoxy - myth or reality?', Journal of the History of International Law 2, no. 2 (2000): 148-177.

Blin, Arnaud, 1648, la paix de Westphalie ou la naissance de l'Europe politique moderne (Bruxelles: Editions Complexe, 2006).

Böhmer, Justus Henning, Introductio in Jus Publicum Universale, Ex Genuinis Juris Naturae Principiis Deductum (Halae Magdeburgicae: Orphanotropheum, 1710).

Braun, Guido, 'Die französische Diplomatie und das Problem der Friedenssicherung auf dem Westfälischen Friedenskongress', in Assecuratio Pacis: Französische Konzeptionen von Friedenssicherung und Friedensgarantie 1648-1815, ed. Guido Braun (Münster: Aschendorff Verlag, 2011), 67-130.

Brunert, Maria-Elisabeth, 'Friedenssicherung als Beratungsthema der protestantischen Reichsstände in der Anfangsphase des westfälischen Friedenskongresses,' In Frieden und Friedenssicherung in der Frühen Neuzeit:Das Heilige Römische Reich und Europa, ed. Guido Braun and Arno Strohmeyer (Münster: Aschendorff Verlag, 2013), 229-258.

Buckisch und Loewenfels, Gottfried Ferdinand von, Observationes Historico-Politicae in Instrumentum Pacis Osnabrugo-Westphalicum (Frankfurt am Main, 1722).

Burgdorf, Wolfgang, Reichsskonstitution und Nation: Verfassungsreformprojekte für das Heilige Römische Reich deutscher Nation im politischen Schriftum von 1648 bis 1806 (Mainz: Philipp von Zabern, 1998).

Burkhardt, Johannes, 'Das größte Friedenswerk der Neuzeit,' Geschichte in Wissenschaft und Unterricht 49, no. 10 (1998): 592-612.

128 I would like to thank Simone Zurbuchen Pittlik and Knud Haakonssen for their useful comments, and Maximilian Fenner for his help in preparing bibliographical material. 
Burkhardt, Johannes, 'Der Westfälische Friede und die Legende von der landesherrlichen Souveränität,' In Landes- und Reichsgeschichte: Festschrift für Hansgeorg Molitor zum 65. Geburtstag, ed. Jörg Engelbrecht and Stephan Laux (Bielefeld: Verlag für Regionalgeschichte, 2004), 199-220.

Cocceji, Heinrich von, Juris Publici Prudentia Compendio exhibita (Frankfurt am Main, 1695).

Conrads, Norbert, Die Durchführung der Altranstädter Konvention in Schlesien 17071709 (Cologne: Böhlau, 1971).

Conring, Hermann, De pace perpetua inter Imperii Germanici Ordines religione dissidentes servanda libelli duo, (Helmstedt: Mullerus, 1657).

Croxton, Derek, The Last Christian Peace: The Congress of Westphalia as A Baroque Event (Basingstoke: Palgrave Macmillan, 2013).

Croxton, Derek, 'The peace of Westphalia of 1648 and the origins of sovereignty,' International History Review 21, no. 3 (1999): 569-591.

Dickmann, Fritz, Der Westfälische Frieden (Münster: Aschendorff Verlag, 1959).

Döring, Detlef, 'Der Westfälische Frieden in der Sicht Samuel Pufendorfs,' Zeitschrift für Historische Forschung 26, no. 3 (1999): 349-364.

Dorpalen, Andreas, German History in Marxist perspective: the East German approach (London: Tauris, 1985).

Droysen, Johann Gustav, Geschichte der preußischen Politik, Dritter Teil, Der Staat des großen Kurfürsten, Erste Abteilung (Leipzig: Verlag von Veit und Comp., 1861).

Duchhardt, Heinz, 'Das "Westfälische System": Realität und Mythos,' in Akteure der Außenbeziehungen. Netzwerke und Interkulturalität im historischen Wandel, ed. Hillard Thiessen and Christian Windler (Cologne: Böhlau, 2010), 393-402.

Duchhardt, Heinz, 'Friedenssicherung im Jahrhundert nach dem Westfälischen Frieden,' in Friedenssicherung. Bd. 3: Historische, politikwissenschaftliche und militärische Perspektiven, ed. Manfred Spieker (Münster: Regensberg, 1989), 11-18.

Duchhardt, Heinz, (ed.), Der Westfälische Friede. Diplomatie, politische Zäsur, kulturelles Umfeld, Rezeptionsgeschichte (Munich: Oldenbourg Verlag, 1998).

Duchhardt, Heinz, Eva Ortlieb, and Matthias Schnettger (eds.), Bibliographie zum Westfälischen Frieden (Münster: Aschendorff Verlag, 1996).

Durst, Benjamin, Archive des Völkerrechts: Gedruckte Sammlungen europäischer Mächteverträge in der frühen Neuzeit (Berlin: De Gruyter Oldenbourg, 2016).

Friedeburg, Robert von, 'Natural Jurisprudence, Argument from History and Constitutional Struggle in the Early Enlightenment: The Case of Gottlieb Samuel Treuer's Polemic Against Absolutism in 1719', in Early Modern Natural Law Theories: Contexts and Strategies in the Early Enlightenment, ed. T.J. Hochstrasser and Peter Schröder (Dordrecht: Kluwer Academic Publisher, 2003), 141-168.

Gerstlacher, Carl Friedrich, Corpus Juris germanici publici et privati: das ist der möglichst ächte Text der teutschen Reichsgeseze, Reichsordnungen und 
andrer Reichsnormalien ; in sistematischer Ordnung mit Anmerkungen (Karlsruhe: Schmieder, 1784).

Geyer, Michael, 'Humanitarianism and human rights: A troubled rapport,' in The Emergence of Humanitarian Intervention: Ideas and Practice from the Nineteenth Century to the Present, ed. Fabian Klose (Cambridge: Cambridge University Press, 2016), 31-55.

Gundling, Nicolaus Hieronymus, Ausführlicher Discours über das Natur- und VölckerRecht (Frankfurt am Main, 1747).

Gundling, Nicolaus Hieronymus, Vollständiger Discours über des Westphaelischen Frieden (Frankfurt am Main, 1739).

Haakonssen, Knud, 'German natural law,' in The Cambridge History of EighteenthCentury Political Thought, ed. Mark Goldie and Robert Wokler (Cambridge: Cambridge University Press, 2006), 249-29o.

Häberlin, Franz Dominicus, Anmerkungen über die in Johann Carl Königs Selectorum juris publ. P. VIII. c. 16. befindliche Erörterung der Frage: Ob die Crone Frankreich vor einen Erbfeind des H. R. Reichs zu achten seye? (n.p., 1745).

Häberlin, Karl Friedrich, Handbuch des deutschen Staatsrechtes, vol. 3 (Berlin: Vieweg, 1797).

Hammerstein, Notker, 'Christian Thomasius,' in Politische Theorien des 17. und 18. Jahrhunderts: Staat und Politik in Deutschland, ed. Bernd Heidenreich and Gerhard Göhler (Darmstadt: Philipp von Zabern, 2011), 117-140.

Haug, Tilman, Ungleiche Außenbeziehungen und grenzüberschreitende Patronage. Die französische Krone und die geistlichen Kurfürsten (1648-1679) (Cologne: Böhlau, 2015).

Havercroft, Jonathan, 'Was Westphalia "all that"? Hobbes, Bellarmine, and the norm of non-intervention,' Global Constitutionalism 1, no. 1 (2012): 120-140.

Hochstrasser, T.J., Natural Law Theories in the Early Enlightenment (Cambridge: Cambridge University Press, 2000).

Hughes, Michael, Law and Politics in Eighteenth Century Germany: The Imperial Aulic Council in the Reign of Charles VI (Woodbridge: Boydell Press, 1988).

Jouannet, Emmanuelle, 'Des origines coloniales du droit international: à propos du droit des gens moderne au $18^{\text {ème }}$ siècle', in The Roots of International Law - Les fondements du droit international, ed. Pierre-Marie Dupuy and Vincent Chetail (Leiden: Brill, 2014), 649-671.

Kampmann, Christoph, Arbiter und Friedensstiftung: Die Auseinandersetzung um den politischen Schiedsrichter im Europa der Frühen Neuzeit (Paderborn: Ferdinand Schoeningh, 2011).

Kampmann, Christoph, Europa und das Reich im Dreißigjährigen Krieg (Stuttgart: W. Kohlhammer, 2013).

Kampmann, Christoph, 'Das “Westfälische System”, die Glorreiche Revolution und die Interventionsproblematik', Historisches Jahrbuch 131 (2011): 65-92. 
Köhler, Johann David, Kurtzgefaste und gründliche teutsche Reichs-Historie (Frankfurt and Leipzig: Riegel, 1736).

Krause, Johann Christoph, Lehrbuch der Geschichte des Dreyßigjährigen teutschen Krieges und Westphälischen Friedens (Halle, 1782).

Kremer, Bernd Mathias, Der Westfälische Friede in der Deutung der Aufklärung. Zur Entwicklung des Verfassungsverständnisses im Hl. Röm. Reich Deutscher Nation vom Konfessionellen Zeitalter bis ins späte 18. Jahrhundert (Tübingen: Mohr, 1989).

Krieger, Leonhard, The German Idea of Freedom: History of a Political Tradition (Chicago, IL: University of Chicago Press, 1957).

Laudin, Gérard, 'Le Gründlicher Discours über den Westfälischen Frieden de Nicolaus Hieronymus Gundling,' In De la guerre juste à la paix juste: Aspects confessionnels de la construction de la paix dans l'espace franco-allemand (XVIe-XXe siècle), ed. Jean-Paul Cahn, Françoise Knopper, and Anne-Marie Saint-Gille (Villeneuve d'Ascq: Presses Univ. Septentrion, 2008), 125-142.

Leibniz, Gottfried Wilhelm, 'Bedenken welcher Gestalt Securitas publica interna et externa und Status praesens im Reich auf festen Fuß zu stellen,' in G.W. Leibniz Politische Schriften (Darmstadt: Preussische Akademie der Wissenschaften, 1931), vol. 1: 133-214.

Leibniz, Gottfried Wilhelm, Sämtliche Schriften und Briefe, Erste Reihe: Allgemeiner, politischer und historischer Briefwechsel, 25 vols. (Berlin: Akademie der Wissenschaften der DDR, 1983).

Leibniz, Gottfried Wilhelm, Sämtliche Schriften und Briefe, Vierte Reihe: Politische Schriften, 8 vols. (Berlin: Akademie der Wissenschaften der DDR, 1983).

Lyons, Gene Martin, and Michael Mastanduno, Beyond Westphalia?: State sovereignty and international intervention (Baltimore, MD: Johns Hopkins University Press, 1995).

Mably, Gabriel Bonnot de, Le droit public de l'Europe, fondé sur les traités (Amsterdam, 1761).

May, Niels F., Zwischen fürstlicher Repräsentation und adliger Statuspolitik: Das Kongresszeremoniell bei den westfälischen Friedensverhandlungen (Ostfildern: Jan Thorbecke, 2016).

Milton, Patrick, 'Intervening against tyrannical rule in the Holy Roman Empire during the seventeenth and eighteenth centuries,' German History 33, no. 1 (2015): 1-29.

Milton, Patrick, 'The early eighteenth-century German confessional crisis: the juridification of religious conflict in the re-confessionalised politics of the Holy Roman Empire,' Central European History 49, no. 1 (2016): 39-68.

Moser, Friedrich Karl von, Beherzigungen (Frankfurt am Main, 1762).

Moser, Johann Jacob Neues teutsches Staatsrecht (Stuttgart: Mezler, [1967]), vols. 1, 7 .

Moser, Johann Jacob, Von der Garantie des Westphaelischen Fridens; nach dem Buchstaben und Sinn desselbigen (Stuttgart, 1767). 
Nifterik, G.P. van, 'Religious and humanitarian intervention in sixteenth and early seventeenth century legal thought,' in Sovereignty and the Law of Nations (16th-18th Centuries), ed. Randall Lesaffer and Georges Macours (Brussels: Peeters Publishers, 2006), 35-6o.

Osiander, Andreas, 'Sovereignty, international relations, and the Westphalian myth,' International Organization 55, no. 2 (2001): 251-287.

Philpott, Daniel, Revolutions in Sovereignty: How Ideas Shaped Modern International Relations (Princeton, NJ: Princeton University Press, 2001).

Pufendorf, Samuel, An Introduction to the History of the Principal Kingdoms and States of Europe ed. Michael J. Seidler, transl. Jodocus Crull (Indianapolis, IN: Liberty Fund, 2013).

Pufendorf, Samuel, Of the Nature and Qualification of Religion, in Reference to Civil Society, ed. Simone Zurbuchen, transl. Jodocus Crull (Indianapolis, IN: Liberty Fund, 2002).

Pufendorf, Samuel, The Divine Feudal Law: Or, Covenants with Mankind, Represented, ed. Simone Zurbuchen, transl. Theophilus Dorrington (Indianapolis, IN: Liberty Fund, 2002).

Pufendorf, Samuel, The Present State of Germany, ed. Michael J. Seidler, transl. Edmund Bohun (Indianapolis, IN: Liberty Fund, 2007).

Pufendorf, Samuel, The Whole Duty of Man According to the Law of Nature, ed. Ian Hunter and David Saunders, transl. Andrew Tooke (Indianapolis, IN: Liberty Fund, 2003). Pütter, Johann Stephan, Der Geist des Westfälischen Friedens; nach dem Buchstaben und Sinn desselbigen (Göttingen: Vandenhoeck und Ruprecht, 1795).

Pütter, Johann Stephan, Historische Entwicklung der heutigen Staatsverfassung des teutschen Reiches Vol. 3 (Göttingen: Vandenhoeck, 1788).

Raeff, Marc, The Well-Ordered Police State: Social and Institutional Change through Law in the Germanies and Russia, 1600-180o (New Haven, CT: Yale University Press, 1983).

Randelzhofer, Albrecht, Völkerrechtliche Aspekte des Heiligen Römischen Reiches nach 1648 (Berlin: Duncker \& Humblot, 1967).

Ranke, Leopold von, Französische Geschichte, vornehmlich des 16. und 17. Jahrhunderts, vol. 2 (Stuttgart: Koehler, 1954).

Recchia, Stefano and Jennifer M. Welsh (eds.), Just and Unjust Military Intervention. European Thinkers from Vitoria to Mill (Cambridge: Cambridge University Press, 2013).

Repgen, Konrad, 'Der Westfälische Friede: Ereignis und Erinnerung,' Historische Zeitschrift 267, no. 1 (1998): 615-647.

Rousseau, Jean-Jacques, The Political Writings, ed. Charles E. Vaughan, 2 vols. (Cambridge: Cambridge University Press, 1915).

Schmauss, Johann Jacob, Academische Reden und Vorlesungen über das teutsche Staatsrecht (Lemgo, 1766). 
Schmauss, Johann Jacob, Einleitung zu der Staats-Wissenschafft, und Erleuterung des von ihm herausgegebenen Corporis Juris Gentium Academici und aller andern seit mehr als zweyen Seculis her geschlossenen Bündnisse, Friedens- und CommercienTractaten, vol. 1 (Leipzig: J.F. Gleditsch, 1741).

Schmauss, Johann Jacob, Kurtzer Begriff der Reichs-Historie, in einer accuraten chronologischen Ordnung (Leipzig: im Verlag Johann Ludwig Gleditschs, 1720).

Schmidt-Biggemann, Wilhelm, 'Leibniz,' in Politische Theorien des 17. und 18. Jahrhunderts: Staat und Politik in Deutschland, ed. Bernd Heidenreich and Gerhard Göhler (Darmstadt: Philipp von Zabern, 2011), 149-151.

Schmidt, Georg, 'Der Westfälische Frieden - eine neue Ordnung für das alte Reich?', in Wendemarken in der deutschen Verfassungsgeschichte: Tagung der Vereinigung für Verfassungsgeschichte, ed. Reinhard Mußgnug (Berlin: Duncker \& Humblot, 1993), 45-84.

Schmidt, Georg, 'Die Idee "deutsche Freiheit”: Eine Leitvorstellung der politischen Kultur des Alten Reiches,' in Kollektive Freiheitsvorstellungen im frühneuzeitlichen Europa (1400-1850), ed. Georg Schmidt, Martin van Gelderen, and Christopher Smigula (Frankfurt am Main: Peter Lang, 2006), 159-189.

Schnur, Roman, Der Rheinbund von 1658 in der deutschen Verfassungsgeschichte (Bonn: Röhrscheid, 1955).

Schröder, Peter, 'The constitution of the Holy Roman Empire after 1648: Samuel Pufendorf's assessment in his Monzambano,' The Historical Journal 42, no. 4 (1999): 961-83.

Schröder, Peter, 'The Holy Roman Empire as a model for Saint-Pierre's projet pour rendre la paix perpétuelle en Europe,' in The Holy Roman Empire, 1495-1806: A European Perspective, ed. Peter H. Wilson and R.J.W. Evans (Leiden: Brill, 2012), 35-50.

Senkenberg, Renatus Karl von, Darstellung des Osnabrück- und Münsterischen oder sogenannten Westfälischen Friedens, nach der Ordnung der Artikel (Frankfurt am Main: Gebhard und Körber, 1804).

Sheehan, James, German History, 1770-1866 (Oxford: Clarendon Press, 1989).

Simms, Brendan, "A false principle in the Law of Nations": Burke, state sovereignty, [German] liberty, and intervention in the age of Westphalia,' in Humanitarian Intervention: A History, ed. Brendan Simms and D.J.B. Trim (Cambridge: Cambridge University Press, 2011), 89-110.

Simms, Brendan, 'Europe's shifting balance of power,' in The Oxford Handbook of Early Modern European History, 1350-1750, vol. 2: Culture and Power, ed. Hamish Scott (Oxford: Oxford University Press, 2015), 649-65o.

Sofer, Sasson, 'The Prominence of Historical Demarcations: Westphalia and the New World Order,' Diplomacy and Statecraft 20, no. 1 (2009): 1-19.

Steck, Johann Christoph Wilhelm, 'Abhandlung von den Rechten und Pflichten der hohen Garans des Westphälischen Friedens,' in Abhandlungen aus dem deutschen 
Staats- und Lehnrecht zur Erläuterung einiger neuen Reichsangelegenheiten (Halle: Johann Justinus Gebauer, 1757), 99-132.

Steiger, Heinhard, 'Die Gewährung der Gewissensfreiheit durch Ernst Casimir von Ysenburg-Büdingen im Jahre 1712,' in Festschrift für Walter Mallmann, ed. Otto Triffterer and Friedrich von Zezschwitz (Baden-Baden: Nomos, 1978), 293-318.

Steiger, Heinhard, 'Konkreter Friede und allgemeine Ordnung - zur rechtlichen Bedeutung der Verträge vom 24. Oktober 1648,' in 1648: Krieg und Frieden in Europa, ed. Klaus Bußmann and Heinz Schilling (Münster: Bruckmann, 1998), 137-146.

Stolleis, Michael, Geschichte des öffentlichen Rechts in Deutschland, vol. 1: Reichspublizistik und Policeywissenschaft 16oo-180o (Munich: C.H. Beck, 1988).

Thomasius, Christian, Essays on Church, State, and Politics ed. Ian Hunter, Thomas Ahnert, and Frank Grunert (Indianapolis, IN: Liberty Fund, 2007).

Thompson, Andrew C., Britain, Hanover and the Protestant Interest, 1688-1756 (Woodbridge: Boydell Press, 2006).

Tischer, Anuschka, 'Grenzen der Souveränität: Beispiele zur Begründung gewaltsamer Einmischung in "innere Angelegenheiten” in der Frühen Neuzeit,' Historisches Jahrbuch 131 (2011): 41-64.

Treitschke, Heinrich von, Deutsche Geschichte im 19. Jahrhundert (Leipzig: Verlag von S. Hirzel, 1879).

Tuck, Richard, The Rights of War and Peace: Political Theory and the International Order from Grotius to Kant (Oxford: Oxford University Press, 1999).

Vattel, Emer de, The Law of Nations, Or, Principles of the Law of Nature, Applied to the Conduct and Affairs of Nations and Sovereigns, with Three Early Essays on the Origin and Nature of Natural Law and on Luxury ed. Béla Kapossy and Richard Whatmore (Indianapolis, IN: Liberty Fund, 2008).

Vetter, Johann Friedrich, Rechtliches Bedenken über drey wichtige, die Religions-Freyheit in dem Heiligen Römisch-Teutschen Reiche betreffende, Fragen; Aus dem Instrumento Pacis Westphalicae, und zwar dessen V. und VII. Articul, erwiesen u. abgefasset (Wetzlar: Nikolaus Ludwig Winkler, 1752).

Wehberg, Hans, 'Die Schieds- und Garantieklausel der Friedensverträge von Münster und Osnabrück,' Die Friedens-Warte 48, no. 6 (1948): 281-289.

Westphal, Siegrid, Der Westfälische Frieden (Munich: C.H. Beck, 2015).

Westphal, Siegrid, 'Reichskammergericht, Reichshofrat und Landfrieden als Schutzinstitute der Reichsverfassung,' in Schutz der Verfassung: Normen, Institutionen, Höchst- und Verfassungsgerichte, ed. Thomas Simon and Johannes Kalwoda (Berlin: Duncker \& Humblot, 2014), 13-50.

Whaley, Joachim, Germany and the Holy Roman Empire: Volume II: The Peace of Westphalia to the Dissolution of the Reich, 1648-1806 (Oxford: Oxford University Press, 2012). 
Wilson, Peter H, Europe's Tragedy: A New History of the Thirty Years War (London: Penguin Books, 2010).

Wilson, Peter H, The Holy Roman Empire. A Thousand Years of Europe's History (London: Penguin Books, 2016).

Wilson, Peter H, War, State and Society in Württemberg, 1677-1793 (Cambridge: Cambridge University Press, 1995).

Wolff, Christian, Grundsätze des Natur- und Völckerrechts, worinn alle Verbindlichkeiten und alle Rehte aus der Natur des Menschen in einem beständigen Zusammenhange hergeleitet werden (Halle, 1754).

Zedler, Johann Heinrich, Grosses vollständiges Universal-Lexicon aller Wissenschafften und Künste, vol. 55 (Leipzig, 1748).

Zschackwitz, Johann Ehrenfried, Einleitung zu dem Teutschen Jure publico, oder StaatsRechte (Leipzig, 1710).

Zschackwitz, Johann Ehrenfried, Geschichtsmäßige Erläuterung des westfälischen Friedens (Halle, 1741).

Zurbuchen, Simone, 'Vattel's "Law of Nations" and the Principle of Non-Intervention,' Grotiania 31 (2010): 69-84.

Zurbuchen, Simone, 'Emer de Vattel on the Society of Nations and the Political System of Europe,' in System, Order, and International Law. The Early History of International Legal Thought from Machiavelli to Hegel, ed. Stefan Kadelbach, Thomas Kleinlein, and David Roth-Isigkeit (Oxford: Oxford University Press, 2017), 263-281. 